\title{
Entrepreneurs, Firms and Global Wealth since 1850
}

\section{Citation}

Jones, G. "Entrepreneurs, Firms and Global Wealth since 1850." Harvard Business School Working Paper, No. 13-076, March 2013.

\section{Permanent link}

http://nrs.harvard.edu/urn-3:HUL.InstRepos:10647830

\section{Terms of Use}

This article was downloaded from Harvard University's DASH repository, and is made available under the terms and conditions applicable to Open Access Policy Articles, as set forth at http:// nrs.harvard.edu/urn-3:HUL.InstRepos:dash.current.terms-of-use\#OAP

\section{Share Your Story}

The Harvard community has made this article openly available.

Please share how this access benefits you. Submit a story.

\section{Accessibility}


H A R VAR D

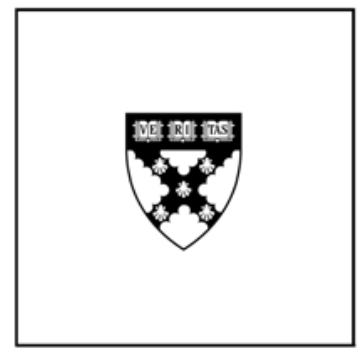

\section{Entrepreneurs, Firms and Global Wealth since 1850}

Geoffrey Jones

\section{Working Paper}

13-076

March 12, 2013 discussion only. It may not be reproduced without permission of the copyright holder. Copies of working papers are available from the author. 
Entrepreneurs, Firms and Global Wealth since $1850^{1}$

\section{Overview}

We live today in a world where most people are poor and some are very rich, and the category in which you find yourself is largely determined not by your job, your age or your gender but by your location. Despite the fast economic growth of China and India over the past two decades, most people in the world today are very poor. Nearly 3 billion people live on less than $\$ 2$ a day; almost 1 billion are illiterate. These numbers reflect the continuing wealth gaps between the West and the Rest of the world, as well as the burgeoning wealth gaps inside countries such as China and India, as well as in the developed world.

Although the data is contested, most economic historians would subscribe to the view that the large inequality between regions is relatively "new," at least in historical terms. The timing, however, remains contentious. A broad consensus that incomes had diverged between Europe and China in the early modern period was disrupted around 2000 when Pomeranz put the term “the Great Divergence” into scholarly usage by suggesting that certain regions of China, India, and Western Europe were at broadly similar levels of agricultural productivity, commercial development and the ability of some firms to raise capital in the middle of the eighteenth century. The Great Divergence in wealth between the West and the Rest, then, began with the Industrial Revolution and the advent of modern economic growth in Britain. ${ }^{2}$

The Pomeranz hypothesis provoked a surge of quantitative research on comparative income levels. Much of this research has suggested that income levels between Europe and Asia were already wide in the eighteenth century, and that this reflected trends which began at least three hundred years earlier. However it has also become clear that the real income gap was between the most advanced countries in Europe - Britain, the Netherlands and Belgium - the 
other regions, whether China, India or central and southern Europe. What happened during the nineteenth century was that much more of the West caught up to the advanced North Sea countries, but the Rest did not. ${ }^{3}$

The large income gaps between the developed West and the Rest in 1914 does not mean that there was no convergence. As Bénétrix, O’Rourke and Williamson have shown, from the late nineteenth century the "periphery" began to follow the path of industrialization set in the West. ${ }^{4}$ A number of Latin American countries began such “convergence” from the 1870s, followed by some Asian countries after 1890, followed by parts of sub-Saharan Africa and the Middle East during the interwar years. However the emergence and growth of modern industrial sectors was not sufficient to close the substantial income gaps which had opened. Today the differentials between the West and most of the Rest remain substantial, even if recent decades has seen some convergence between China and other non-Western countries and the West.

Business historians have not been central to the debates about the Great Divergence. As an academic discipline, business historians have been primarily concerned to understand why Western countries, and subsequently Japan, grew wealthy. The most important contribution of this literature has been to identify the modern business enterprise as central to the economic performance of economies. Chandler documented the growth in nineteenth century America of large-scale corporations with professional managers, who he and others drove industrial innovation. ${ }^{5}$ Much subsequent business history research has gone into testing this hypothesis, including exploring how, why and with what consequences, firms and business systems in other Western countries looked different from those in the United States. ${ }^{6}$ There has been much less research on the converse of this situation: why, and with consequences, the entrepreneurs and 
firms in Latin America, Africa and most of Asia were so delayed in producing powerhouses of corporate innovation.

In contrast economists, as well as other social scientists, have made major advances in understanding what kept countries poor as well as what made them rich, even if the conclusions remain contested. During the 1970s North identified the role of institutions in providing the incentive structure of economies. He defined institutions quite broadly. He believed that they "consist of both informal constraints (sanctions, taboos, customs, traditions, and codes of conduct), and formal rules (constitutions, laws, property rights). ${ }^{7}$ Greif, another prominent institutionalist, defined them as "a system of rules, beliefs, norms and organizations that together generate a regularity of (social) behavior.”8 In his more recent work, North himself has widened his own definitions of institutions even wider, and argued that responses to institutions are heavily conditioned by culturally conditioned mental models and religious beliefs. ${ }^{9}$

In practice, the primary focus of attention has been systems of property rights. It has been asserted that societies that provide incentives and opportunities for investment will be richer than those that fail to do so, and that the protection of property rights was an essential incentive behind such investment. By reducing transactions costs and facilitating potential gains from exchange, institutions fuel productivity and growth. The literature has particularly favored the use of three proxies in particular for "institutions": risk of expropriation; government effectiveness and constraints on the executive. North famously identified the Glorious Revolution in England in 1688 as providing the institutional arrangements which explain why that country had the Industrial Revolution. ${ }^{10}$

Although most economists now agree that inherited institutions matter for growth, however, they have disagreed on the nature of this institutional foundation. There has been a 
considerable emphasis in recent literature on impact of colonialism. Engerman and Sokoloff highlighted the impact of colonization in altering the composition of the populations. In Latin America and Caribbean, soils and climates gave them a comparative advantage in growing crops for which they used slaves or natives. The resulting extreme inequality in distribution of wealth, they suggest, gave them institutions which contributed to persistence of substantial inequality. In North America, few Native Americans and climates and soils favored mixed farming and livestock with limited economies of scale in production got the right kind of institutions. ${ }^{11}$

Acemoglu, Johnson and Robinson distinguished between institutions of "private property" and "extractive institutions". The former provide secure property rights and are embedded in a broad cross-section of society. Extractive institutions concentrate power in the hands of a small elite and create a high risk of expropriation. These authors use this model to explain what they describe as the reversal of fortune between apparently affluent (as proxied by urbanization) Aztecs and Incas in Americas and Mughals in India, and little developed North America and Australia. They argue that this was caused by European colonialism. In prosperous and densely settle areas, Europeans introduced or maintained extractive institutions to force people to work in mines and plantations. In sparsely settled areas, Europeans settled and created institutions of private property. The spread of industrial technology in the nineteenth century required a broad mass of society to participate, so they won out. ${ }^{12}$

A different institutional perspective has come from the law and finance literature. Broadly these authors have argued that the legal tradition countries inherited or adopted in the distant past has a long-term effect on financial development. Countries that had a common law system had on average better investor protections that most civil law countries, and that French civil law countries were worse than German or Scandinavian civil law traditions. They suggest 
this had a major effect on financial development, which in turn can be assumed to have impacted the nature and speed of economic development. ${ }^{13}$

A second explanation for wealth and poverty has focused on human capital. Thirty years ago Easterlin argued that the answer to why some societies underwent modern economic growth and others did not could be found in the amount of formal schooling provided by societies. Within Europe, the most advanced nations educationally, in northern and Western Europe, were the ones that developed first. Easterlin also speculated that the content of education matters, believing that secular and rationalistic was best. ${ }^{14}$ Subsequently, Goldin has made a strong case for attributing American industrial leadership to the unique egalitarian mass provision of post elementary schooling achieved in the United States during the early twentieth century. ${ }^{15}$ Scholars in the law and finance literature have accepted that human capital may be a more basic source of growth than institutions, and that growth and human capital accumulation lead to institutional improvement. ${ }^{16}$

This economics literature has made great progress in developing new ways to measure and identify the causal effects of key variables, but it also has limitations. literature remains split on methods, data and interpretation. Much of the work can be criticized by its willingness not to overly engage with historical specifics. The focus on the impact of colonialism skirts around an unusually big elephant in the room often called the "Needham Puzzle" after one of the most prominent historians of technology in China: why did China not have an Industrial Revolution. Although poor institutions - “Oriental Despotism” - are often blamed for this, there is as much evidence that the Chinese state was benign or weak than that it was predatory. The widespread existence of market activities and the importance of private property in China would support such a view. At the very least, there were such considerable fluctuations over time in the 
effectiveness of governments in China, and in their relationship to market activities, that a monolithic “Oriental Despotism” explanation is not convincing. ${ }^{17}$

On a more conceptual level, the economics literature is heavily oriented towards measurement and causality. Knowing that political and legal institutions or human capital matter is important - but a further set of critical questions relate to how firms and entrepreneurs interact with these aspects of an economy. It is firms and entrepreneurs which create wealth and innovation, rather than governmental institutions or schools. Here the economics literature is less well-developed. Institutions and human capital are treated as the first order causes of economic growth. The assumption is that if a society evolves or adopts the right institutions, or else has good human capital investment, firms and entrepreneurs will more or less appear spontaneously and create economic growth. The business history literature suggests that this is a considerable over-simplification.

This working paper seeks to incorporate the missing gap of firms and entrepreneurs into debates about the causes of global wealth and poverty. It is not intended here to revisit the extensive literature why the Industrial Revolution occurred first in Britain. Instead, the focus is more on why much of the Rest struggled to catch up.

\section{Are some countries just more entrepreneurial than others?}

One reason why economists may not have spent much time thinking about the role of business enterprises in the Great Divergence is that there is not an interesting story to tell. Are some countries simply more entrepreneurial than others because of cultural factors? If the answer is yes, then there is no need to explore more complex mechanisms which may be at work.

The view that the culture was just wrong has been widely used to explain the Needham Puzzle. By the fourteenth century China had an advanced agriculture with high yields, a 
considerable knowledge of science and technology, a verge large iron and textile industry, and a high level of urbanization. ${ }^{18}$ The only thing wrong, as Weber wrote in The Protestant Ethic and the Spirit of Capitalism, was the Chinese mindset. ${ }^{19}$ Joseph Needham, whose research documented the achievements of pre-modern science and technology in China, came to the same view, as has more recently the economic historian Mokyr. ${ }^{20}$

This issue was also much discussed by earlier generations of business historians before the discipline became primarily focused on organizational issues during the 1960s. Between the late 1940s and the late 1950s the Center for Research in Entrepreneurial History at Harvard assembled an interdisciplinary group of scholars, including economists such as Joseph Schumpeter, North and young historians such as Chandler and David Landes, who pursued empirical studies on the rise of entrepreneurship in the transition to capitalism, examining the emergence and social conditioning of entrepreneurship in countries around the world. This stream of research resulted in a body of literature, focused on the historical development of entrepreneurship, which suggested that levels of entrepreneurship did vary significantly between countries. ${ }^{21}$ For some, the reason lay in culture. In a classic early study, Landes argued that France's allegedly poor economic performance in the nineteenth century could be attributed to the conservativeness of French entrepreneurs, who saw business as an integral part of family status rather than as an end in itself. ${ }^{22}$ Landes continued throughout his career to make the case for the importance of national cultural factors, values, and social attitudes in explaining the development of entrepreneurial activity, and in turn the economic performance of nations. ${ }^{23}$ The cultural failure argument appeared in many other debates. Gentrified and complacent British entrepreneurs in the Victorian Era proved a favorite subject for those interested in explaining the “relative decline” of the British economy. ${ }^{24}$ 
From the start there have been major criticisms of the cultural approach. It is known that in history peoples who shared similar cultures or beliefs had very different paths of development. Often the problem being explained was poorly specified. Landes's search for why French entrepreneurs failed was launched without a clear understanding of what, if anything, had failed. Nineteenth century French industry is now regarded as a lot more technologically advanced than had been imagined. ${ }^{25}$ As the economist Alexander Gerschenkron noted, the notion of "national culture” envisioned in many studies was static and rigidly functionalist, making it difficult for them to truly account for the dynamic nature of entrepreneurial activity or for entrepreneurial change. ${ }^{26}$ Schumpeter maintained that entrepreneurs often acted as agents of change rather than being captives of their environment. While national institutions and political boundaries, whether formal or informal, provide the environmental settings for entrepreneurial activity, Schumpeter insisted that they often revealed little about the ways in which new economic opportunities have been created and exploited. ${ }^{27}$

In short, while entrepreneurship is a scarce resource, it is at best insufficient to use inherent cultural differences to explain variations in entrepreneurial and economic performance between countries. This does not mean that variations in cultural and social values at particular points in time might not form part of an explanation why the economic performance of countries diverged. It does mean that such variations demand more complex explanations than inherent cultural differences. The paper now turns to examining the role of entrepreneurs and firms in creating wealth and poverty in the historical phases of globalization, constrained and reglobalization since the second half of the nineteenth century. 


\section{Creating Wealth and Poverty in the First Global Economy}

The global integration of the markets for capital, commodities and people proceeded at a fast pace from the 1820s, and especially from the 1870s as transport and communications costs fell through technological advances, and political barriers to investment fell with the spread of both liberal political ideologies and Western imperialism. Globalization transformed national economies. While Western countries underwent rapid industrialization, countries in the South and Asia were turned them into major exporters of commodities and foodstuffs. The scale of transformation was sometimes enormous. India’s huge handicraft manufacturing industry lost its markets abroad and increasingly in major cities, and the country became instead a major primary commodity exporter. While tea had been barely grown in South Asia in the 1830s, India had become the world's largest tea producer by 1900, as British firms both developed plantations and pursued innovative marketing strategies which overturned the previous dominance of Chinese tea from the world market.

The domestic entrepreneurial response to these momentous economic shifts in most of Asia, Latin America and Africa was not strong. While many regions of Europe caught up with the home of modern industrialization around the North Sea, the Rest as a whole lagged over the course of the nineteenth century. This was surprising in some respects. There were strong commercial and market traditions in much of Asia and to some extent elsewhere. There were long-established handicraft industries in China and India, as well as deep commercial and financial institutions. Expatriate Chinese in Southeast Asia had good mining skills, and developed and dominated the tin mining industry in Malaya after 1848. Much of Latin America descended into decades of political turmoil and strife following independence from Spain in the early nineteenth century, but from mid-century stronger political units formed, and economic 
growth resumed, especially in the southern cone. Argentina eventually became one of the world's fast-growing, and richest, economies. ${ }^{28}$ Yet dynamic and innovative locally-owned firms were slow to emerge from these regions.

So why was it entrepreneurs originating from Western countries which surged ahead of the Rest during the nineteenth century? The institutional argument that entrepreneurship was more likely to flourish in a country which protected property rights, did not expropriate and functioned effectively than in chaotic or rapacious regimes seen in some if not all of the nonWestern world, is a starting point, at least for countries outside colonial empires. But what was the exact relationship? A major insight is provided by Baumol's work on the allocation of entrepreneurial activity. Two decades ago Baumol argued that the productive contribution of entrepreneurship varied because of the allocation between productive activities such as innovation and unproductive activities such as rent seeking or organized crime. This allocation, Baumol suggested, was in turn influenced by the relative pay offs offered by a society to such activities. ${ }^{29}$ A subsequent large-scale collaborative research project provided much empirical historical support for this hypothesis, including a re-statement of the key typologies into productive or redistributive entrepreneurship. ${ }^{30}$

The Mexican financial system from the late nineteenth century shows how this mechanism played out in one country by demonstrating how the existence of an undemocratic political system and selective enforcement of property rights shaped the financial and business system. Limited in its ability to raise taxes to finance infrastructure projects as well as fend off political opponents, Maurer has shown how the Mexican government of the dictator Porfirio Diaz relied on banks to provide credit, while the banks relied on the government to enforce property rights. A select few bankers were given extensive privileges producing a highly 
concentrated banking system. Each bank grew fat in its own protected niche. To overcome the problems associated with information asymmetry, banks lent to their own shareholders and other insiders. In the case of the textile industry, banks did not lend to the best firms, but the bestconnected firms. Poorly defined property rights prevented those excluded from the insider networks from pledging collateral and finding another financial route. ${ }^{31}$

There were parallels in the more successful business sector in Argentina. During the late nineteenth century large business groups such as Bemberg and Tornquist grew rapidly. They diversified across commodities, processing, infrastructure, and consumer goods manufacturing. These large and successful businesses were productive in Baumol's terms, opening up new industries, and driving the country's fast development at the time. From another perspective, however, there impact was redistributive. They build businesses on the basis of concessions from the government, and devoted considerable energy to political contacts. They were also heavily engaged in financial transactions and networks. As industries developed, they opted to continue importing heavy machinery rather than face the cost of investing in making such machines themselves, and in training skilled workers. As a result, the technological capabilities of the country remained basic. ${ }^{32}$

As studies of nineteenth century Mexico and elsewhere, have shown, as the West pulled away, technological catch-up was a huge entrepreneurial challenge. The new advanced technologies of the West were embedded in quite different institutional, economic and social contexts than in the Rest. Entrepreneurs could not simply import them and they would work. Factor endowments fundamentally shaped the commercial viability of different transferred technologies. ${ }^{33}$ Relevant technologies needed to be identified, they need to be adapted, they needed to be financed, and they needed to be used. This was hugely challenging, although not 
impossible. $^{34}$ This explains, in part, why there were such significant regional differences in entrepreneurial performance in many nineteenth century Latin American countries, despite having the same institutions at the national level..$^{35}$

Conversely, getting the institutions right is often regarded as a key factor behind Japan's unusually successful entry into modern economic growth following the Meiji Restoration in 1868. The resource-poor island nation of Japan seemed an unlikely candidate for economic success. The institutional heritage of the country seemed to make such success even less likely. During the sixteenth century Japan's Shogun military rulers had largely closed the country to foreign trade, expelled foreigners, and imposed a strict feudal regime. This regime had remained in place for centuries before the US navy ships of Commodore Perry had turned up in Tokyo harbor in 1853 demanding that the country open itself up for foreign trade. The Meiji Restoration was effectively a coup by lower samurai, a sub-elite group, based in a few outlying regions of the country, who were determined to resist Western incursion into the country. The new Japanese government moved rapidly, and in the face of rebellions by disaffected former members of the feudal elite, to create a modern institutional infrastructure, including a parliamentary system, a central bank and a legal system, by explicitly copying institutions in the Western countries.

The institutional reforms of the Meiji era resemble a Baumol-approved strategy for generating a supply of productive rather than redistributive entrepreneurship. ${ }^{36}$ Yet the institutional framework constructed in Meiji Japan was surely not one which many of today's institutional theorists would favor. Despite appearances, they were not embedded in a broad cross-section of society - indeed their basic purpose was to extract resources from the mass of the people in order to take the country on a forced march of rapid industrialization, and to wage war on and colonize neighboring countries. 
In part, the growth of modern entrepreneurship within this institutional context might be ascribed to the pre-industrial commercial heritage of the country, where a market economy had flourished despite the feudal regime and closed economy. A number of the family owned zaibatsu or business groups which drove modern industrial growth, notably Mitsui, drew on such long-established business traditions. Mitsui had been founded as early as 1673 as a clothing retailer. Yet the firm's subsequent growth as well as new entrants such as Iwasaki Yataro's shipping company Mitsubishi was driven by political patronage. In order to support the government's colonial expansion plans and suppress internal rebellions, Mitsubishi was given ships, credit and protection against foreign shipping companies by governments during the 1870s. Business-government relations seem closer to nineteenth century Mexico than to the United States, although there was a great deal more tension between Yataro and the government than between the Mexican business elite and Diaz. ${ }^{37}$

Closer examination of the "institutional arrangements" which promoted growth in many countries in the first global economy raise many questions about the "right" and "wrong" institutions to promote entrepreneurship and firm growth. For example, protection of intellectual property rights and patents would appear important to promote entrepreneurship from an institutional perspective. Yet the evidence that patents in Britain played an important role in the Industrial Revolution and later is weak. The cost of obtaining a patent in eighteenth century Britain was high, and they were difficult to enforce. ${ }^{38}$ Later aspiring nineteenth century Dutch entrepreneurs were able to build businesses in more technologically advanced industries because of the lack of patent protection afforded to foreign companies in those countries. ${ }^{39}$ Indeed, Moser's review of the historical evidence strongly suggests that in countries with patent laws the majority of innovations have occurred outside of the patent system, while conversely countries 
without patent laws produced as many innovations as countries with patent laws during the same time periods, and their innovations were of comparable quality. ${ }^{40}$

There are other important examples when empirical research has challenged the correlation between institutions and entrepreneurship seem. It was plausible to suggest, for example, that the emergence of larger-scale Chinese business during the nineteenth century was handicapped by the absence of company law and limited liability. Finally, in the Company Law passed in 1904 provided the legislative framework for modern business. On closer examination, however, it turns out that the law was a culmination of trend which had been underway for several decades to facilitate the raising of outside capital. Moreover few Chinese companies registered under the act when it was passed. Most entrepreneurs continued to rely on their own and their family funds. ${ }^{41}$ In the case of Brazil in the same period, Musacchio has raised serious doubts concerning the adverse impact of civil law regimes on financial and economic development. Brazil was a French civil law country with apparently inadequate creditor protection and contract enforcement, but he found that Brazilian firms used their own byelaws to offer strong protection for equity investors. The country developed a very strong corporate bond market before 1914, which then shrank in importance despite continued creditor protection. ${ }^{42}$

The role of colonialism poses the most serious challenge to institutional explanations of variations in the allocation of entrepreneurial energy. Colonialism forms an important element of the institutional economics explanation for the lack of growth in developing countries, but much of the treatment is ahistorical. Colonialism changed greatly over time, but most attention is given to the highly exploitative first stages of European colonialism. While colonialism is from today's perspective wholly unacceptable, there was a huge difference between Spanish conquistadores in the sixteenth century looting the Aztec and Inca empires, and pious (if racist) late Victorian 
British colonial officials in India and Africa. There was a huge difference between those Victorian officials and their rapacious eighteenth century predecessors in the East India Company. The policy regime of empires changed over time. While traditional Indian handicraft industries suffered from British free trade policies in the nineteenth century, during the interwar decades British India was protectionist, including against British imports. In general, empire was a heterogeneous rather than a homogeneous phenomenon. British colonies got common law systems, while French colonies got civil law systems, with all the consequent different alleged effects on corporate governance. In Africa, while the vast Belgian possessions in the Congo in the late nineteenth century have long been regarded as a prime example of worst-case exploitative imperialism, in the British colonies the relationship between the colonial administration and expatriate business were much more distant and nuanced. ${ }^{43}$

The late nineteenth century British colonial regime is especially interesting for its impact on entrepreneurship. The British brought not only political stability, but their legal system with protection of property rights and contract enforcement. The empire even offered the prospect of upward social advancement for highly successful business leaders of any ethnicity. Ethnic Indian, Jewish, Chinese and other diaspora moved within the imperial umbrella, frequently being co-opted into the British imperial system. By the late nineteenth century Indian and others were being given Knighthoods. ${ }^{44}$ In 1892 Dadabhai Naoroji, an Indian, became the first Asian elected to the British House of Commons.

This raises a puzzle why the response to modern economic growth by entrepreneurs in India was muted. The British administrators in India not only introduced British company laws, they simplified and codified them in ways which appear to have made them even more enterprise-friendly. The British Raj also operated a laissez-faire, low tax policy regime. ${ }^{45}$ Yet 
when investments began in large-scale industry from the mid-nineteenth century, they were highly clustered geographically and ethnically. Scotsmen developed the modern jute industry of Calcutta from the 1860s, whilst the tiny ethnic minority of Parsees developed the textile industries on the west coast. Modern indigenous entrepreneurship became, and has remained, highly concentrated ethnically, with the Marwaris originating from Rajasthan and the Vanias from Gujerat joining the Parsees as the dominant entrepreneurial groups at least until the second global economy. ${ }^{46}$ It would certainly be possible to construct an argument that colonialism and the institutional racism that went with it impacted entrepreneurial cognition. In crude terms, entrepreneurs who were not white men from Western countries may have felt less qualified to pursue opportunities, even if they were not. However this does not readily explain why some ethnic groups became dynamic entrepreneurs in India.

There are some puzzles, therefore, about the historical relationship between institutions and entrepreneurship is not wholly straightforward, therefore, and the same goes if we explore the relationship with human capital. In striking contrast to Goldin's description of education in early twentieth century America, many countries in nineteenth century Asia, Latin America and Africa had limited formal education provision largely confined to the elites. This may have affected the supply of domestic entrepreneurship in many non-Western countries in the nineteenth century. There is a large literature on developed countries on the importance of professional managerial cadres as firms grew, and of the role of educational institutions in the background of such managers. Poor educational levels for the mass of the population also made the management of labor far more difficult because of poor skill levels and low productivity. The lack of a theory of the supply of entrepreneurship means that the exact impact of low human capital development on the level and allocation of entrepreneurship is less clear cut. It is 
probably safe to assume, however, that extreme social inequality, poor literacy levels and lack of technical education reduced the available pool of productive entrepreneurs in many countries. In the case of colonial India, the high cost of skilled labor has been identified as one important reason, alongside other resource constraints including the high cost of capital, why the country remained inclined to small-scale traditional manufacture. ${ }^{47}$

The quality of Japanese human capital development was plausibly an important driver of the faster development of modern entrepreneurship and management there. Japan had achieved high literacy levels well before Perry arrived in 1853. The Meiji regime enacted compulsory primary education in 1872, before Britain and many other Western countries, and established the first Western-style universities soon afterwards. The zaibatsu were recruiting large numbers of university graduates as managers by the 1900 s. $^{48}$

Much still remains to be understood about the relationship between education, entrepreneurship and managerial effectiveness. In nineteenth century Europe, Sweden’s high educational levels even when it was very poor, peripheral economy has been widely regarded important in enabling the country to "catch up" as the century progressed. ${ }^{49}$ Yet eighteen and nineteenth China had widespread literacy which did not translate into modern economic growth. ${ }^{50}$ Argentina's fast economic growth during the first global economy can be correlated with the highest literacy rate in Latin America. In 1900 the country’s literacy rate of 52 per cent was far above Mexico’s 22 per cent and Brazil’s 25 per cent, if far lower than the literacy rates of the United States and Canada. ${ }^{51}$ Yet such educational attainments could not prevent the country's subsequent poor economic performance for the remainder of the twentieth century.

Nor can human capital be treated as entirely exogenous to firms. Early Japanese industrialization was plagued by skill shortages. Japanese firms responded with in-house 
training, beginning with shipyards in the 1890s. In turn, a better trained workforce was able to learn and diffuse techniques from abroad. Centuries of seclusion left Japan with a lack of knowledge of foreign countries and languages. One response was the institutional innovation of using specialist trading companies to engage in importing and exporting. These giant firms, based on the British trading companies in Asia, rationed scarce managerial resources and provided a means to share knowledge about foreign markets and sources of supply. ${ }^{52}$

This brief survey of the historical evidence suggests that neither institutions nor human capital are fully discrete, and that historical case studies provide different answers to the question about what matters most. There are likely to have been other factors at work also. To have entrepreneurship, there must be entrepreneurial opportunities. The growth and size of the American market provides a key component of the Chandlerian explanation for the emergence of large integrated firms in the United States. It seems plausible that both in the case of Britain, the first industrializer, and Japan, the first successful non-Western catch-up, identification of entrepreneurial opportunities, and the building of managerial structures which permitted their exploitation, was facilitated by geographically compact domestic markets and unusually large capital cities.

The market opportunities for firms and entrepreneurs in most of Asia, Latin America and Africa were more constrained. They often faced great difficulties if they wanted to sell beyond their local markets because of poor transport and communications infrastructure. In India, market conditions have been identified as one explanation why India's powerful and rich merchants in the seventeenth and eighteenth centuries left manufacturing in the hands of small artisans, pointing to fragmented markets, inadequate transport infrastructure, lawlessness and disregard for property rights. ${ }^{53}$ These constraints were relaxed as the British colonial regime imposed 
political stability and promoted transport infrastructure, but a well-established argument in the literature on nineteenth century India has maintained that the small scale of the domestic market retarded the growth of a modern machinery industry. ${ }^{54}$

Yet it was often foreign firms, or ethnic minorities, which took advantage of expanding opportunities. There may well have been an issue of entrepreneurial cognition. Most local entrepreneurs may not have been well-informed about the pace of change in advanced economies, and less knowledgeable about their markets, including the market for skilled expertise. Language may have been a factor. A lack of English-speaking ability might have constrained access advanced knowledge in Latin America. The former imperial powers, Spain and Portugal, were in the backward south of Europe, and were not good role models of modern industrial growth.

Despite the criticism earlier of the overgeneralizations and stereotypes found in the broad cultural explanations of entrepreneurial performance, there has been a renewed interest in the view that cultural values are likely to have framed cognition and exploitation of opportunities. North's search for explanations of the "wide and still widening gap between rich and poor countries" has led him to consider the importance of immensely varied cultures with different combinations of supernatural beliefs and institutions. ${ }^{\text {} 55}$ The problem remains how to really test such a hypothesis against historical evidence. Cross-cultural management theory offer one avenue, by showing how cultures both differ in core values, and how this affects (if not determines) business organization and firm strategies. Hofstede’s classic study identified four dimensions of culture which differed between countries: readiness to tolerate inequality (Power Distance); tolerance for uncertainty (Uncertainty Avoidance); relationships between the individual and the collective (Individualism); and attitudes towards gender roles (Masculinity). 
Hofstede added a new dimension of "Long-Term Orientation” during the late 1980s, followed by a sixth dimension called Indulgence versus Restraint in $2010 .^{56}$

It is not implausible to believe, if challenging to demonstrate robustly, that the northern European and Anglo-Saxon combination of individualism and tolerance for uncertainty yielded advantages to their firms in entrepreneurial endeavors over those in many developing countries, especially at the time when starting new industries was quite risky. It is believed, for example, that Chinese mining firms lost out to Western firms in early twentieth century Malaya because they did not want to risk making large capital investments in new technologies. ${ }^{57}$ Of course it is debatable if the cultural characteristics identified by Hofstede, which is based on a study of a large number of IBM employees in 1980, bear much relationship to the cultural values in the nineteenth century. It is known that cultural characteristics change slowly because they are passed on through child-rearing practices, but it is also known that exogenous shocks and in some cases government policies can shift cultural values.

Mark Casson has gone furthest in identifying the features of societies which may cause them to differ in their receptiveness of entrepreneurship. He defines an "entrepreneurial culture" using theories of entrepreneurship that emphasize the functions of innovation, risk-bearing, and arbitrage. Entrepreneurial cultures, he proposes, can thus be defined in terms of attributes - such as scientific and systems thinking - that promotes or retards these functions in a society. Cultural differences towards information and "trust" levels may have been especially important in explaining variations in the quality of entrepreneurial judgments. ${ }^{58}$

It is evident that business enterprises in many non-Western societies were often challenged to grow beyond a certain size because their societies found it hard to "trust" nonfamily members as either managers or equity holders. Japan was an unusual society where 
"blood ties" were not decisive in determining trust levels. Arguably, the rapid Japanese move to employing professional managers may have reflected cultural traditions of adopting sons. In science-based industries, in which the optimal scale of production is large, a willingness to employ professional managers became important. Chandler famously ascribed British relative decline against the United States in the late nineteenth century to a preference for family firms rather than professional management. As originally constructed, however, the argument has attracted much criticism, and indeed spurred a vibrant literature on the merits of family owned and managed business. ${ }^{59}$

The early literature from the Harvard Center and others on entrepreneurs and firms in non-Western countries was weakened by assumptions that deviations from American managerial practices should be a priori regarded as a sign of failure, or evidence of irrational cultural values. Much of the early literature on Latin American entrepreneurship in the nineteenth century blamed lack of economic growth on an alleged commercial and speculative ethos of the region's entrepreneurs. The diversified business groups which appeared during and after the nineteenth century in Latin America and elsewhere were regarded as inherently inefficient, and driven by social and political motivations rather than business logic. However, while the predominance of family owned diversified business groups with strong links to political elites is uncontested, later research has provided a better understanding of the rationality behind organizational structures such as diversified business groups arising from weaknesses in capital markets, shortage of managerial resources, and high transactions costs. Within such conditions, business groups can, and often are, often the most effective forms of business organization. In other words, they are more characterized as examples of productive than redistributive entrepreneurship. ${ }^{60}$ 
Somewhat similarly, Indian firms in the newly created modern textile industry of the mid-nineteenth century innovated institutionally by abandoning the partnership form favored by their British counterparts and forming joint stock companies linked into wider groups by equity, debt and cross-directorships. The resulting "managing agency" system, long disparaged in the literature as an idiosyncratic morass of conflicts of interest, is now seen as an effective organizational response to economic conditions, and subsequently copied by British expatriate firms active in India. ${ }^{61}$

Indeed, as entrepreneurs in developing countries began catching-up with their Western counterparts, they were often successful in developing hybrid organizational forms well-adapted to their local contexts. In China, the new modern business enterprises which appeared in early twentieth century typically combined the formal organization of Western-style corporations with traditional, well-established business practices from China's pre-industrial past. A study of the rapid growth of Shanghai's print machinery industry from the late nineteenth century has shown that in this industry, unlike others such as textiles, Chinese entrepreneurs were so successful that they were able to replace foreign machine imports with products from the local machine industry. ${ }^{62}$

However, the pre-eminence of ethnic and religious minorities in entrepreneurial activity does point towards some combination of cultural and institutional explanations of retarded entrepreneurship. As many Asian, African and Latin American countries began to industrialize, minorities or immigrants were especially important in new firm creation. These included Chinese in south-east Asian, Indians in east Africa, Lebanese in West Africa, Italians in Argentina, and French in Mexico. ${ }^{63}$ Their success was often ascribed to particular ethical or working practices, but their role is more plausibly explained as a demonstration of the challenges faced by 
entrepreneurs in societies where trust levels were poor, information flows inadequate, institutions weak and capital scarcity. In such situations, small groups with shared values held major advantages as entrepreneurs. If in addition, they established an intermediary role between "more local locals” and Western firms, they could secure easier access to knowledge and information, from and about, Western countries.

The prominent role of a few groups in modern industry in India from the nineteenth century has received much attention. The importance of the tiny Parsee community around Bombay has been variously described as the result of close relations with the colonial authorities, “outsider" minority status, and a "Protestant" style work ethic. ${ }^{64}$ The Marwaris were far less close to the British. Indeed, a number of families, like the Bajaj who financed and supported Gandhi's campaign of non-resistance against the British, were active in the Independence struggle. Other explanations have been found in unique cost accounting methods and the work ethos which seems to feature in most accounts of minority successes. ${ }^{65}$

Wolcott has combined both cultural and institutional factors to explain the pre-eminence of Indian minorities. She relates the situation to India's caste system, and argues that the payoffs to entrepreneurship differed across caste lines. Members of the moneylending and trading castes like the Marwaris could enforce contracts through reputation and membership deterred cheating. As a result, they were efficient at providing financial and other resources to entrepreneurs within their own castes. However, the large number of potential entrepreneurs outside these groups lacked privileged access to these informal financial networks, reducing their incentives to engage in productive entrepreneurship. ${ }^{66}$

The ethnic clustering in modern entrepreneurship in India, and elsewhere, was striking, but as Roy has suggested, another way to look at such clustering was geographically. Before 
1914 Bombay and Calcutta accounted for half the modern factories in India, and even more of related services such as banking and insurance. Unlike other cities in India, they had grown through the activities of the East India Company, and were outward-oriented and cosmopolitan. In these two port cities, Roy observes, "modern Indian business enterprise and business families congregated and recreated a globalized world with strong Indian characteristics.” 67

The emergence of hubs such as Bombay, and modern entrepreneurship in general, took place within the context of the wider political economy environment. With perhaps the single exception of Britain in the eighteenth century, governments have contributed to entrepreneurship and firm growth not only by providing (or not providing) institutional rules of the game, but through a wide range of policy measures. The role of the state in catching up economic backwardness has been debated since the writings of Gershenkron decades ago ${ }^{68}$ However, the ways in which governments facilitated entrepreneurial perception and exploitation of opportunities has not been the primary emphasis of this research. Yet it is difficult to account for the rapid economic growth of the United States in the nineteenth century without mentioning government policy. The Federal government purchased, or annexed, much of the territory of the present day country, and then largely gave it away. State governments were active promoters of infrastructure investment. High levels of tariff protection widened the market opportunities for entrepreneurs and firms by shutting out cheaper imports from Europe. ${ }^{69}$ The Japanese government was prevented by Western countries from tariff protection, but it subsidized the first modern factories before privatizing them. It distorted markets by favoring zaibatsu through subsidies and the allocation of business. The government was not center-stage in the first wave of Meiji industrialization, as many of its interventions were poorly managed or not purposeful, but it provided a broadly favorable context for entrepreneurship. ${ }^{70}$ 
We can see the impact of the wider political economy in other settings. Explanations for why ethnic Chinese business became disproportionately important in Southeast Asia typically stress cultural factors, including the role of family, dialect groups and the Confucian value system. With respect to the latter, it has often been argued that social trust, the social obligations that bind family and lineage, was strengthened by the Confucian belief, and that provided the bedrock of commercial networking. Yet while some or all of these features may be significant, the growth of Chinese entrepreneurship in Southeast Asia also has to be placed within a wider political economy context. From the fourteenth century, the region's rulers favored foreign over local merchants because the latter might pose a political threat. Through the seventeenth century local trading communities, whether Malay or Filipino, continued to flourish, but the Chinese role was strengthened by the arrival of Western merchants, for the Chinese positioned themselves as intermediaries. By the late nineteenth century, the Chinese had secured the position of revenue farmers across the region, both in colonial and non-colonial areas. This made them indispensable for local and colonial governments, while providing a source of funds for their business interests. $^{71}$

There are other examples of the importance of public policy in shaping entrepreneurial opportunities and outcomes in the nineteenth century. Take the fundamental shift in comparative advantage in the global copper industry away from Chilean dominance in the mid-nineteenth century to US dominance by the 1890s. By the end of the century, US firms were not only outcompeting Chilean ones in the export market for copper but were also undertaking FDI in production in South America. The competitive advantage of US firms was developed by an array of public policies that supported the development of the infant industry in the United States. 
Industrial mining and smelting of copper prospered in the nineteenth century not because of free enterprise, but precisely its opposite, which was the extent and quality of government. ${ }^{72}$

Conversely, when local governments were able to change the rules of the game for their firms, the result was often if not always the creation of productive business enterprises. Take the case of late nineteenth century Uruguay. Its banking market had been dominated by British banks. However in 1896 a local bank was formed which the government gave the sole right of note issue. By 1914 it had captured a large share of the domestic banking market. This formed part of a wider story of the growth of viable and successful locally owned banks in Latin America. In Argentina, a first wave of local banks failed disastrously in the early 1890s. However a second generation, which explicitly adopted many of the prudent lending practices which characterized British banks and combined them with more entrepreneurial policies of opening numerous branches, was much more successful and by 1914 had captured well over half the Argentinian banking market. ${ }^{73}$

Less direct forms of geopolitical power also played a growing role in expanding opportunities for international entrepreneurs from powerful countries, especially after the turn of the century. For instance, "Dollar Diplomacy," an official US government policy first implemented in the early twentieth century, provided State Department support for US enterprises operating in Latin America. Such diplomatic (and often implicit military) backing was often important for entrepreneurs and firms making large fixed investments abroad or in negotiating special concessions from a host government. In the case of certain forms of crossborder entrepreneurship, such as in natural resources, infrastructure, and agriculture, diplomatic influence and assistance were often critical for attaining the kinds concessions needed to do business. $^{74}$ 
It was within the context of Western geo-political power that European and US firms surged abroad to the Rest looking for commodities and markets. By 1914 world FDI was not only substantial compared to world output, it was also primarily located in the non-Western world. Latin America and Asia were especially important as host regions, representing 33 and 21 per cent respectively of the total world stock of FDI. ${ }^{75}$ If domestic entrepreneurship in many developing countries struggled to get traction, it needs to be explained why foreign entrepreneurship did not exercise a more productive effect on local business systems.

The industrial composition of this FDI provides a partial answer. Possibly one half of total world FDI was invested in natural resources, and a further one-third in services, especially financing, insuring, transporting commodities and foodstuffs. Manufacturing FDI primarily went to serve the markets of the West, whilst most FDI in the Rest was either in resources or services.

Yet the establishment and maintenance of mines, oil fields, plantations, shipping depots, and railroad systems involved the transfer of packages of organizational and technological knowledge to host economies. Given the absence of appropriate infrastructure in developing countries, foreign enterprises frequently not only introduced technologies specific to their activities, but also social technologies such as police, postal and education systems. Insofar that lack of financial resources handicapped local firms, foreign banks contributed to building modern financial infrastructures. The British overseas banks which operated in Asia, Africa and Latin America may have been focused on trade finance and found it safer to lend to expatriates than locals, whose creditworthiness was hard to assess, but they were more flexible in their lending policies than had once been thought. ${ }^{76}$ Moreover it is not evident that availability of finance was the major handicap to entrepreneurship in the Rest. There were high levels of 
Chinese investment in foreign shipping and insurance companies, banks, and manufacturing companies before 1914, and Chinese business men sat on the boards of companies. ${ }^{77}$

Perhaps a greater positive impact came from the building of transport and distribution infrastructure which enabled entrepreneurs to access world markets for the first time. British, French and other civil engineering and construction firms built railroads, ports and harbor facilities, bridges, urban sanitation systems, dams, electricity and gas works all over Latin America, Asia and parts of Africa. Between the late nineteenth century and 1914 residents of most of the world's cities were provided with access to electricity, in their homes or at work, or else in the form of street lighting. ${ }^{78}$ A global communications network based on submarine cables was put in place. In so far as access to markets had been a constraint, these investments relieved it.

However spillovers and linkages to local entrepreneurs were limited by the nature of global capitalism at the time. Many natural resource investments were enclavist. Minerals and agricultural commodities were exported with only the minimum of processing. Most value was added to the product in the developed economies. Foreign firms were large employers of labor at that time, but training was only provided to local employees to enable them to fill unskilled or semiskilled jobs The French-controlled Suez Company, which built and operated the Suez Canal in Egypt between 1854 and 1956, had a major stimulus on the Egyptian economy, but until 1936 the Egyptian staff was almost exclusively unskilled workers. ${ }^{79}$

The nature of the industries and these employment practices meant that the diffusion of organizing and technological skills to host economies was far less than to developed economies. Diffusion worked best when there were already established firms which could be stimulated to become more competitive by foreign firms, or had the capacity to absorb workers who moved on 
from foreign firms. This was the case in Japan, where - for example - the long established textile machinery manufacturer Toyoda was able to recruit workers from the US auto companies Ford and General Motors in the interwar years to build its new Toyota subsidiary. The process was facilitated by nationalistic government policies focused on removing the US-owned firms from the country. ${ }^{80}$

Nor were foreign companies typically transformers of domestic institutions. While theoretically they may have been channels to transfer aspects of the institutional arrangements in their home countries to their hosts, for the most part they reinforced local institutions. This was most directly seen in the concession system. In order to entice firms to make investments in mines, railroads, and so on, foreign firms were often given large concessions often involving freedom from taxation and other requirements over very long periods. It is not easy to imagine alternative options. Local entrepreneurs typically lacked knowledge of and access to foreign markets where these products were sold. They ability to hire foreign managers was constrained by reputation as much as by capital. However in some cases local dictators also preferred to give contracts and concessions to foreign entrepreneurs than to local entrepreneurs for domestic reasons, not wishing to build up powerful domestic rivals.

Concessions worked to lock-in already sub-optimal institutional arrangements even when they had positive economic outcomes. In Mexico, President Diaz's contracts and concessions to the British engineering contractor Weetman Pearson was effective in securing major infrastructure improvements in railroads, ports and the drainage of Mexico City, and Pearson also laid the basis for the successful Mexican oil industry.Yet Pearson's very success strengthened the autocratic and crony capitalist regime of Diaz. ${ }^{81}$ 
Elsewhere the downsides of the concession system were even more apparent. A prime example is the malign influence of United Fruit, the US banana company, in central American countries such as Guatemala. This country had emerged as an independent nation in 1821 with an unequal social hierarchy based on race. The white population was positioned at the top, owned the majority of the land and controlled the political system through a series of dictators. The second class consisted of so-called "ladinos"-the mixed-race population or Westernized Indians. At the bottom was the majority of the population, composed of Mayan descendants. Guatemala had an unstable political system after independence from Spain in 1821. In 1898, General Manuel Estrada Cabrera took power, and stayed in power by repeated re-elections of questionable legitimacy until 1920. During his presidency, he encouraged investment in infrastructure, promoted export of goods, and gave United Fruit its first concessions for banana cultivation. The country was transformed into a "banana republic" with bananas dominating the export economy. Cabrera and his successors saw United Fruit as a vehicle to modernize the country through its investments in railroads, telegraph lines, housing, as well as plantations. However the plantation system also re-inforced the unequal social structures in Guatemala, which served as a massive obstacle to the development of a more entrepreneurial culture. Moreover, because the position of United Fruit was supported by the United States government, change was made even harder to achieve. When during the early 1950s the democratically elected government of Jacobo Arbenz sought to achieve agrarian reform, with the specific aim of developing a market economy, it was overthrown in a CIA-inspired coup, a military dictator put in its place, and United Fruit restored to its lands. ${ }^{82}$

The nature of the first global economy, then, meant that there was limited diffusion of entrepreneurship and organizing capabilities from Western firms in developing countries. Their 
primary impact was often to lock-in countries as resource providers, and to reinforce institutional constraints on domestic entrepreneurship rather than removing them. This partly explains why the domestic entrepreneurial response to globalization was weaker than might have been imagined, which at its heart lay in a lagged understanding of the opportunities offered by the new global economy combined with problems building effective business organizations which could absorb foreign technological and organizational skills. Public policy was one way to break constraints on local entrepreneurs - it was certainly effective in promoting the growth of the United States - but few governments in developing countries had either the autonomy or the capacity to pursue effective public policies.

However by 1914 the evidence, patchy as it might be, suggests that the lag was being addressed in India, China, and some countries in Latin America. The business enterprises being built, whether Japanese zaibatsu, Latin American business groups or hybrid Chinese manufacturing firms, were often not US-style managerial corporations, but they were quite effective responses to local conditions.

\section{Globalization Constrained}

The outbreak of World War 1 in 1914 began a process which saw the meltdown of the first global economy. The levels of integration in capital and commodity markets fell back sharply to levels seen in the mid-nineteenth century. During the 1930s high tariffs and tight exchange controls closed down the global economy in favor of regional trading blocs and currency areas. This represented a reversal of globalization. There was a new interest in the nationality of ownership, and a growing resentment beyond the West in the ownership of assets by foreign firms. The Russian Revolution in 1917 was followed by the sequestration of foreign property. By the 1930s political nationalism was rampant. The Mexican nationalization of 
foreign oil companies in 1938 was a landmark event which asserted national sovereignty over natural resources. ${ }^{83}$ It is less evident if the term de-globalization is fully justified. De Grazia has explored how the global consumer culture which had emerged during the late nineteenth century continued to expand and deepen during the interwar years. ${ }^{84}$ Miller's study of the maritime world of shipping, trading and ports identified continuities throughout the era of so-called deglobalization. ${ }^{85}$ Business historians have also showed how multinational investment persisted through the 1930s, and took new forms such as cartels. The term constrained globalization might be a better description. ${ }^{86}$

In part, the growth of policy restrictions global capitalism should be seen as the result of a revolt of the people who had not done well out of the globalization of the previous decades. Nineteenth century-style global capitalism had made some Western countries rich, and left the remainder more aware that they were relatively poor. It had frequently strengthened inequalities, and had locked countries into positions of being resource providers. There were many other losers, such as the peoples subject to the indignities of colonialism, and Muslims who perceived their religion and its values were denigrated by Western colonialism.

The two world wars and the Great Depression caused enormous damage to global welfare, but were not without their benefits for entrepreneurs and firms in developing countries. It expanded market opportunities for such firms by cutting supplies from Europe, or protecting local firms from foreign competition. Japan's precocious modern industrial growth, underwritten by large state spending, was rescued from a likely meltdown by World War 1 , which enabled its textile and other industries could break into other Asian markets. In India, and other European colonies, the War accelerated a shift of political power to local people as nationalism accelerated. Foreign firms for the first time began to consider Indians and Africans for filling managerial 
posts - not through a sudden conversion to the merits of diversity in the workforce, but because they were short of money and locals were cheaper than expatriates.

There was a strong growth of Indian-owned business from the World War 1. Modern industrialization spread from the small confines of parts of Western and eastern India to many other regions of India. A major turning point was the entry of the Marwaris into industry. During the War Ghanshyam Das Birla led the Marwari community into its first sustained manufacturing investments. He was offended by the racism he encountered from the British, but he also studied and learned from them about modern business methods. During the interwar years the Marwaris and others greatly expanded their manufacturing investments, sometimes by buying the shares of British companies. Indian entrepreneurs invested in new industries such as sugar, paper, shipping and chemicals, and challenged the British incumbents in jute and coal. ${ }^{87}$

There was also a significant growth of modern Chinese entrepreneurship, despite numerous institutional and infrastructure failings, and the determined efforts of the Nationalist governments of the interwar years to regulate and control the economy. ${ }^{88}$ Zhang Jian founded the Dasheng textile mills in Nantong in 1895, and this business evolved during the interwar years into a diversified business group in textiles, flour and oil milling, land development and shipping. ${ }^{89}$ In a study of the pharmaceutical and Chinese medicine industry, Cochran has shown how Chinese entrepreneurs employed innovative advertising, retailing and other strategies to build large businesses both in China and in Southeast Asia. ${ }^{90}$

There was evidence in the Middle East, too, of local entrepreneurs establishing modern business enterprises. In Egypt, under British occupation from the 1880s, new entrepreneurs were drawn from diverse nationalities, including Egyptian and British, became active in economic diversification and industrialization, often in quite imaginative ways. Bank Misr was the creation 
of Egypt's dynamic business innovator, Tal'at Harb, who endeavored to promote new directions in the Egyptian economy after World War I. Influenced by the German great banks of the nineteenth century and believing that a large-scale, heavily capitalized, and Egyptian-run bank could lead the country out of its economic dependence on cotton exports, Tal'at Harb founded the bank and used its capital to create a host of Misr companies, including in textile manufacturing, shipping, and air travel. Bank Misr finally crashed in 1939 after becoming overextended and experiencing some serious managerial failures. ${ }^{91}$

In Turkey, also, modern entrepreneurship appeared. The Republic of Turkey was established in 1923 out of the ruins of the former Ottoman Empire, and led by the modernizing general, Kemal Atatürk. In the nineteenth century Ottoman Empire, business had been primarily in the control of religious and ethnic minorities such as Greeks, Armenians and Jews, many of whom were killed or fled the country following traumatic events during and after World War 1. The new government offered subsidies and other support to aspiring entrepreneurs, and during the 1930s established public enterprises to drive modern economic growth and employed selective policies that led to the dispossessing of non-Muslim businesses. Within this context, Vehbi Koç was one of a new generation of Islamic Turks who began to build businesses. Beginning in grocery and leather, he moved into construction, securing multiple government contracts during the 1930s, as well as acting as a distributor for Ford automobiles. After making very large profits from truck importing during World War 2, a war Turkey stayed out of until just before the end, Koç began to build what became Turkey's largest diversified business group during the post war decades. ${ }^{92}$

These entrepreneurial pioneers across the Rest faced multiple challenges. Chinese firms, for example, had to deal with chronic political instability, and the Japanese military attack on the 
country after 1931. Many countries were badly affected by the Great Depression and secular decline in commodity prices. Building managerial competences was hard. Family businesses, as most of the ventures were, faced constant tensions as they grew in scale and needed expertise beyond the family. Often, even as nationalistic sentiments rose, local entrepreneurs simply faced a credibility gap even from their compatriots that they could be as competent as Western firms. Given the challenges, however, the catch-up of business in parts of the Rest during the interwar years was perhaps even more striking.

During the post-1945 decades a new global economy began to emerge in the capitalist countries of the West and Japan as trade barriers and exchange controls were lowered. However, much of the Rest either opted out of global capitalism, or sought to highly regulate it. As the European colonial empires were dismantled, there was often an aggressive reaction against the businesses of the former colonial power, and sometimes all foreign investment. The relatively small number of expropriations without compensation until the 1970s - when a period of largescale expropriation began - reflected the power and determination of the United States to protect foreign investments, but Western countries were unable to re-establish an international legal regime which guaranteed the property rights of international investors. During the 1970s Western ownership of much of the world's natural resources, including oil, minerals and plantations, ended.

The postwar political environment was not well-designed for the diffusion of entrepreneurial skills or organizational capabilities to the Rest. As political risk and government restrictions mounted, Western MNEs focused investment, trade and knowledge flows on other developed countries. These countries offered the primary markets for advanced technological and consumer products. In new advanced technology industries, MNEs located different parts of 
the value chain in different countries. In semi-conductors, for example, from the 1970s firms such as Intel placed assembly stages in developing countries, but the higher value added activities were located in developed countries. ${ }^{93}$ Overall, by 1980 two-thirds of world FDI was located in Western Europe and North America. Britain alone hosted more foreign direct investment than the whole of Africa and Asia combined. Within the developing world, there was enormous concentration of inward FDI. In Asia, for example, most FDI was located in a handful of South-east Asian countries. ${ }^{94}$

This was the classic era of the large M-form corporations which served as the powerhouse of innovation in high technology manufacturing industries. US-based firms were pre-eminent in new technologies such as computers, and they typically sought to maintain innovation and other value-added activities within firm boundaries. ${ }^{95}$ There was geographical clustering of knowledge also. During the 1950s and 1960s an unusual convergence of technological skills, educational institutions, and venture capital in California's Silicon Valley, combined with a pleasant climate, encouraged the emergence and clustering of numerous entrepreneurial firms which were to dominate innovation in many parts of the IT industry. ${ }^{96}$

MNEs concentrated innovation in their home countries. This may not always have been the case. There is aggregate evidence from patent data that the internationalization of technological activity by large manufacturing firms was quite extensive by the interwar years, but it then declined. ${ }^{97}$ After 1945 US and Japanese firms especially did their innovation at home. European companies conducted more innovation in foreign laboratories, but they were located overwhelmingly in other European countries or the United States. The firms with the most dispersed innovatory technology were in "traditional” industries such as food, drink and tobacco, building materials and petroleum. In computers, aerospace and motor vehicles, there was a 
strong propensity to concentrate technological activities at home. ${ }^{98}$ Few MNEs undertook basic R \&D in developing countries. A rare exception was Unilever’s affiliate in India. In general, however, cutting-edge technological advanced knowledge was locked within the boundaries of large Western firms, or else in clusters located primarily in the United States, notably Silicon Valley.

Nevertheless, there were some spillovers from MNEs in developing countries in the middle decades of the twentieth century. Large Western firms such as Unilever, Shell, and Citibank became important sources of management training in developing countries and important diffusers of management knowledge. The local managers recruited by these firms sometimes joined local firms, or launched start-ups. Unilever was at the forefront of recruiting "locals" to management positions in India and other developing countries from the 1950s. Citibank was also a large recruiter and trainer of managerial talent in developing countries. ${ }^{99}$

. A second spillover came from the emulation of foreign business models. Avon, the leading American direct seller in beauty industry, began expanding to developing countries from the 1950s. The model proved especially relevant to developing countries as it enabled thousands of women sales people to earn extra income from direct selling, and become quasi-entrepreneurs in the process. The evident success of the business model spawned local competitors during the 1960s and 1970s, such as Brazil's Natura, which grew to be Brazil’s largest beauty company. ${ }^{100}$

Yet between 1945 and 1980 many countries in the Rest looked to models other than firms like Avon or global capitalism in general to catch up. At one extreme, the Communist regimes in the Soviet Union, Eastern Europe, China and elsewhere cut themselves off from global capitalism and sought to overcome the constraints on modern economic growth of their countries by making heavy investments in human capital, and by forcibly mobilizing resources to 
promote heavy industries. This Communist model had very mixed results. There were significant achievements in improving educational levels and the manufacture of capital goods. However such overall gains were outweighed by catastrophic policies towards agriculture, the closing of economies to flows of international trade and knowledge, and the creation of institutions which distorted incentives and promoted corruption. Occasionally quasi-capitalist firms were permitted - East Germany allowed some quasi-Mittelstand firms in toys and musical instruments because of their export importance, but for the most part the institutional and cultural consequences of a business system based on a relationship between large-state-owned enterprises and central planners was negative. China’s vast and inefficient state-owned firms became a longterm drag on that country’s economic performance. ${ }^{101}$

At the other extreme, there were a handful of cases of developing countries which fully embraced global capitalism. Virtually from the state's full independence in the mid-1960s, Singapore had one of the most open policy regimes towards foreign MNEs anywhere in the world. Foreign-owned companies drove an export-led labor-intensive export strategy which transformed the country in three decades from a poor island state to one of the world's richest countries in terms of per capita income. However the country relied on the State to develop local firms. A number of State-owned companies, including Singapore Airlines, became successful, global-competitive business enterprises. Singapore Airlines developed a competent management which used imaginative marketing strategies and bold investment strategies to create a world class airline, implausibly located in a country with no domestic air market, providing a role model for the much later success of airlines based in a number of Arabian Gulf states. Singapore was less successful at promoting private sector entrepreneurship. The water treatment company 
Hyflux, founded by female entrepreneur Olivia Lum in 1989 which had revenues of $\$ 450$ million by 2013, was sufficiently atypical to attract constant media attention. ${ }^{102}$

The role of MNE's in driving Singapore's fast economic growth rested on rather specific circumstances. Singapore's initial export strategy coincided both with the new strategies of MNEs in electronics and other industries to embark on policies of world-wide sourcing, and with anti-MNE policies in much of the rest of the developing world. It had a long tradition as a commercial entrepot, had a majority population of overseas Chinese with network links elsewhere in the region, and inherited a set of legal and other institutions from the British, and a wide knowledge of English. Above all the government pursued policies, including repressive controls over wages and political dissent, in an unusually effective fashion. ${ }^{103}$ The level of authoritarianism could probably only have been achieved in a small island.

A less successful version of this strategy was followed by neighboring Malaysia. Malaysia attracted vast investments from electronics companies into free trade zones established after 1971. This was successful in creating exports and jobs. Malaysian employment in electronics grew from 600 in the mid-1970s to 300,000 in 1995. By 2000 electronics accounted for over a quarter of Malaysia's manufacturing employment. However linkages with the surrounding economy were weak and not capable of stimulating local entrepreneurship. This reflected tensions within the country following racial riots between the majority Malays and minority ethnic Chinese in the late 1960s. The Malay-controlled government, concerned that foreign MNEs should not strengthen local Chinese business interests, allowed foreign companies to have 100 per cent ownership of o subsidiaries provided they exported their entire output, thus tacitly discouraging joint ventures with local firms. During the 1980 s 80 per cent of the intermediate products used in electronics manufacturing in the export processing zones were 
imported from abroad. This meant that the industry imported almost as much as it exported in the 1980s. Local firms supplied basic items such as cardboard boxes. Low value-added components - where Malaysian factories usually added only about 30 per cent of the value of the product - accounted for around 80 per cent of the country's electronics sector in the 1980s. Little design or R \& D was undertaken in Malaysia, partly because of a shortage of graduate scientists and skilled technicians. ${ }^{104}$

Most countries fell between the Singapore and Communist models. Japan and South Korea developed trade and investment policy regimes which enabled their firms to access foreign knowledge through licensing and joint ventures, while ensuring that foreign firms were largely prevented from investing in their countries. In Japan, although firms such as Toyota were developing highly innovative management methods which would eventually enable them to sweep away their US competitors, they were also allowed to grow to scale behind high levels of tariff protection, and to export on the basis of an undervalued currency. Government policies were not exogenous to firms - they played a large role in lobbying governments to get the policies they wanted, for example, on the entry of foreign firms into Japan. ${ }^{105}$

The remarkable growth of South Korea from being one of the world's poorest countries in 1960 to the home of global champion firms in a range of manufacturing industries is particularly striking. The story does not fit the institutional model well, for the period of industrial take-off coincided with a repressive military dictatorship. The regime banned trade unions and pursued a protectionist industrial policy which favored a small group of large familyowned business groups known as chaebol, including Samsung, Hyundai, Daewoo and LuckyGoldstar. It was not the protection of property rights or constrained executives which promoted growth, but "good for growth" dictators. 
The chaebol were the principal forces behind South Korean rapid growth as a major force in electronics and automobiles. Hyundai, until its break up in 2001, was the largest chaebol. The firm was founded by Chung Ju-yung in 1947 as a construction firm, and Chung remained directly in control of the company until his death in 2001. From a humble beginning, the firm grew rapidly, entering automobiles from the 1960s, shipbuilding from the 1970s, and electronics from the 1980s. Each stage of growth was shaped by government policy, which provided timely assistance in terms of favorable financing, and domestic market protection. In return, Hyundai built new factories, provided desperately needed jobs, and earned valuable foreign exchange by exporting. Widely condemned as crony capitalism after the 1997 Asian financial crisis, the system also delivered fast economic growth rates over decades and worldclass firms. ${ }^{106}$

In many other developing countries, governments intervened to enable their countries to modernize. There were major, and frequently under-estimated, advances in literacy rates, which were very low at the end of the colonial period in most of Asia and Africa, and in women's political and other rights. Industrial policies were less successful.Many longestablished locally-owned business sectors were destroyed in the new era of state planning and controls. The process could be seen at a micro level in the case of the Bolivan tin industry. Before 1914 the Bolivian entrepreneur Simon Patiño displaced the foreign companies which had initially developed the Bolivian industry to become the largest Bolivian producer of tin concentrates. This output was at first sold to smelters in Britain and Germany. In 1916 Patiño secured control of the British smelter. The high physical asset specificity of the smelters required to deal with Bolivia's lode ores provided an incentive for this strategy. In 1929 Patiño also obtained control of one of the two Malaya smelters. Patino himself moved abroad during the 
1920s, registering his main corporate vehicle in the United States, possibly to raise capital. During the 1930s he formed one of three companies which accounted for almost half of the world's mining and tin smelting outside the Soviet Union, and he was prominent in forming the long-standing tin cartel. But in 1952 Bolivia became the first country to take over its tin industry. Although the Patiño group remained important in the marketing and smelting of tin, it was fragmented because of the loss of ownership of the mines. ${ }^{107}$

The same phenomenon was evident in Africa. By the 1960s the large-scale private sector in Egypt had been entirely dismantled. Nigeria’s business communities, which had appeared as dynamic forces in the postwar decades, became engaged in ethnic and regional rivalry that drew business. In Africa, the most successful firms were seen in South Africa, which underwent fast economic growth between 1950 and 1973. However, these firms grew in the context of the institutionalized racism in the form of the apartheid system adopted after 1948. This forced millions of blacks forced off their farms and urban areas, denying them education. These decades saw the creation of giant industrial groups, often closely linked to the government, although the economy as a whole began to experience poor performance from the 1970s. ${ }^{108}$

In many developing countries, state intervention continued to encourage local entrepreneurs to grow large businesses using political contacts rather than technological capabilities. This did not necessarily prevent the creation of large firms, although it usually provided a weak foundation for international competitiveness. An example might be the Chareon Pokhad (CP) Group, which became the largest Thai-owned MNE. It was founded in 1921 by recent emigrants from China as a small venture selling imported vegetable seeds. It became a major animal feeds manufacturer after World War 2. In 1971 a joint venture with a leading US poultry breeding firm became the basis for the creation of a modern integrated chicken business 
in Thailand. Further diversification followed into real estate and retailing, often through joint ventures with Western firms. However the firm's major growth in telecommunications was achieved through CP's close contacts with leading Thai politicians, while its rapid growth in China after 1979 - where it became one of the largest foreign investors - was based on strong ethnic ties. ${ }^{109}$

There is general agreement that import substitution regimes of this era resulted in inefficient industries which were sheltered from international markets, and often burdened by webs of planning regulations and corruption. Yet capacities were created, albeit inefficient ones. Take the case of Brazil. In the early 1950s Brazil still only the beginnings of an industrial base. Virtually all the motor vehicles used in Brazil were imported as knocked-down kits and assembled locally. During the second half of the 1950s an industrial policy was pursued which threatened assemblers with market closure if they did not manufacture locally. Even more critical was the policy towards the level of local content which meant that firms were forced to produce the "technological heart" of their vehicles in Brazil, which was definitely not on their agenda. Although the large US automobile manufacturers Ford and General Motors initially declined to commit themselves, Germany's Volkswagen, which was just embarking on global expansion, decided to begin making its Beetle car. By 1968 eight foreign firms manufactured 280,000 vehicles in the country. A further surge of growth resulted in annual production of over one million vehicles by 1980 . The level of protectionism had resulted in low productivity, and it was entirely foreign-owned as early ambitions that a locally-owned industry would develop did not come to fruition. Still, Brazil had acquired the tenth largest automobile industry in the world. ${ }^{110}$

It would also appear that import substitution regimes provided local firms with opportunities to achieve scale within their domestic markets. Cemex, now the world's third 
largest cement company, was founded in Mexico in 1906, and was able to grow in a rather sheltered environment slowly becoming a regional player and then, in the 1970s, a national player.

In India, the era of the so-called "License Raj" also enabled firms to grow within their domestic market. Arguably, it laid the basis for the country's subsequently successful IT services sector. Postwar India had growing numbers of engineers owing to the many national institutes, engineering universities and regional colleges established after 1947. However, it had little choice to be totally dependent on US computer makers. During the 1960s and 1970s a handful of locally-owned firms were established to develop and run applications software for Indian companies and research institutions that had brought or leased mainframes from IBM and other US companies. Tata, which had remained India's largest business group, established the first of these firms, Tata Consulting Services in 1968. This and other ventures remained small, however, until 1977, when, after the Indian government tightened the laws on foreign ownership of firms, IBM and other US firms divested.

The departure of IBM opened new opportunities for local firms. TCS developed a relationship with another US computer maker, Burroughs, which provided an important channel of new technology. In 1982 the start-up Infosys was founded by the dynamic entrepreneur Narayana Murthy. The Indian firms built a strong trade association, NASSCOM, which sought to enhance and certify the quality of Indian firms. By the time policy regulation got underway in 1991, which gave Indian IT firms a freer hand in establishing marketing offices abroad and serving foreign clients, it had built strong organizational capabilities. The software industry became focused on Bangalore, where the British had established India's first aircraft factory during World War 2, and which was the home of two of India's premier institutes of higher 
education in pure science. Like Silicon Valley, there was also a pleasant climate, at least before pollution began to increase. The government's establishment of a Software Technology Park, or export zone, in Bangalore in 1990, and an influx of expertise and contracts from the many expatriate Indians employed in Silicon Valley, were other influential factors in the growth of the Bangalore cluster. ${ }^{11}$

A similar tale could be told about other Indian industries. Both long-established business groups and new entrepreneurial firms were able to emerge in the Import Substitution era, despite the formidable battery of government controls and restrictions, and despite a considerable number of firms experiencing problems because of family succession issues. The highly protected domestic market itself created profitable opportunities for incumbents, although a serious-trade off was a widespread spread of corruption. Many new business groups were created, including by Marwari families such as the Goenkas and Khaitans, who built business groups by acquiring former British assets. Although the productively and effectiveness of Indian firms was highly constrained by planning controls and other bureaucratic obstacles, therefore, once policies were changed after 1991 they had the scale to expand rapidly. It was a different legacy from the state-owned companies in China.

The era of constrained globalization, then, was challenging for the catch up of the Rest. During the interwar years there were significant examples of strong locally-owned business enterprises developing in India, China, Egypt and elsewhere. After World War 2, many governments opted for state-led industrialization programs which frequently disrupted local firms, whilst blocking or discouraging foreign MNEs. Protectionism and restrictions on foreign firms did provide a context for new local firms to emerge, although these policies also provided incentives for firms to build skills in political contacts rather than technology. The growth of 
some of the larger business enterprises in the Rest, such as the South Korean chaebol and large South African corporations, took place in the context of authoritarian and repressive regimes, far removed in most respects from the institutional arrangements postulated by North and others as best for capitalist development.

By 1980 the gap in income levels between the rich nations and the Rest was bigger than in 1914. Japan was the only case of a spectacular catch up, with a number of other smaller East and south-east Asian economies following at a distance. Elsewhere, state interventionist regimes had encountered growing problems of macro-economic instability and hyper-inflation by the 1970s. These problems provided the background for the shift back to liberal polices beginning in the following decade.

\section{Second Global Economy}

The world spectacularly re-globalized from the 1980s, even if in some respects - such as immigration - it remains less globalized than before 1914. Among the most dramatic changes has been a worldwide policy embrace of global capitalism as emerging markets countries abandoned state planning and import substitution and sought export-led growth.

The fast economic growth seen in China and India, and certain other regions of the Rest also, provide strong support for Baumol's argument that shifts in the rules of the game can stimulate productive entrepreneurship. It is, once more, less supportive of the institutional argument. China’s resurgence began under another good for growth dictator, Deng Xiaoping, who had little concern with controls over the executive, human rights, political rights or intellectual property protection. In some respects, however, China is a showcase for the transforming impact of global capitalism, as foreign firms played a key role in starting China's 
economic growth, and accounted for a high percentage of China’s exports. By the 1990s inward FDI accounted for 13 per cent of gross domestic capital formation in China. ${ }^{112}$

Debates continue how exactly China’s experience should be interpreted. Huang argued nearly a decade ago that it said as much about the highly inefficient domestic firms which failed to capitalize on opportunities, in part because of continuing government interference in the allocation of financial resources, than it did about the transforming impact of global capitalism. ${ }^{113}$ It is less evident that this argument can be sustained more recently given the growing global competitiveness of a cluster of Chinese firms, often state-owned. For a time there appeared to be an interesting "natural experiment” with Asia’s two largest economies. While China embraced FDI, India made a mirror-image choice. Foreign companies played only a limited role in the Indian economy, while powerful globally competitive firms developed. However, more recently, there has been more inward investment in India than previously.

While MNEs played a dynamic role in China’s economic growth, as they had earlier for Singapore, it is less apparent that this was a general phenomenon. Policy regimes everywhere shifted towards openness, and many countries started to offer incentives to MNEs to invest, rather than passing laws to block them. However, most research on the impact of foreign MNEs was sobering. There remained little or no aggregate evidence of spillovers from MNE to local firms in the same sector, especially in developing countries. There was convincing evidence of positive linkages between MNEs and suppliers in many developing countries. Foreign affiliates were often more demanding in their specifications and delivery targets, while more willing to provide assistance and advice to local firms. ${ }^{114}$ However in countries where export-oriented FDI was concentrated within free trade zones, linkages with local firms were often been weak. 
MNEs needed to cross the 'border' in order to source locally, and they often preferred to source in neighboring countries.

One explanation for limited spillovers was that MNEs had clear incentives to minimize leakages to real or potential competitors. In many developing countries local firms also continued to lack the capabilities to compete with large MNEs, and the greater the technology gap, the more difficult this gap was to fill. In branded consumer goods, such as cosmetics, foreign entry often resulted in local firms retreating into the lower end of the market, competing on cost rather than innovation. Research increasingly suggests that large MNEs struggled even with transferring organizational knowledge across borders even within their own firm. As such corporations grew in complexity, the organizational obstacles to knowledge diffusion may have expanded. ${ }^{115}$

Nor was there evidence that MNEs were any more able, or willing, to change growthrestricting institutions. For example, the development of business in many of the poorest countries is handicapped by high corruption levels. Before the 1980s many MNEs probably contributed to these corruption levels. More recently, most have been less willing than local firms to engage in bribery and tax evasion, in part because of the threat to corporate reputation as well as home country regulations such as the Corrupt Practices Act in the United States, but they do not have the capacity to change societal norms for the most part. In important markets, foreign firms typically will lend support to institutional norms, as seen in the willingness of US firms such as Cisco, the internet networking company, to facilitate the Chinese government's censorship of the internet and curbing of political dissent. ${ }^{116}$

A further limitation on the impact of MNEs was that as firms moved resources across borders in pursuit of profitable opportunities, not social good per se, they were more likely to 
reinforce trends than counter them. Despite the availability of technologies which permit the dispersal of economic activities, the second global economy saw a strong trend towards the geographical clustering of higher value-added activities, whether they be Silicon Valley, Bangalore, the City of London, or coastal regions of China.

In some instances, especially where the knowledge component of activities was not great, MNE strategies were footloose as a result. The experience of Mexico's maquiladoras - foreignowned factories that assemble imported components for export - provided one example. These originated in 1965, when the United States and Mexico started a Border Industrialization Program, designed to reduce regional unemployment in the northern territories of Mexico. USowned firms including GE, RCA, IBM, Coca-Cola and Ford were the first to locate their production in Mexico. There was a rapid growth of production following the 1982 Mexican debt crisis, when wage rates fell sharply. Employment in the maquiladoras rose from 100,000 in 1982 to 500,000 in 1992. The implementation of NAFTA in 1994 resulted in a further boost. By 2000 employment had reached 1.3 million, and the sector accounted for over 40 per cent of total Mexican exports. However there were two downsides. First of all, there were practically no Mexican spin-offs from all this investment. Secondly, the investment was vulnerable to greater attractions elsewhere. Between 2001 and 2004 employment the Mexican maquiladoras fell by 200,000 as firms shifted factories to China, although rising wage costs in China substantially reversed this trend over the following decade.

Nevertheless, certain aspects of global capitalism evolved in ways which delivered more opportunities for firms and entrepreneurs based in the Rest. An important development was the disintegration of the boundaries of M-form firms during the 1970s and 1980s, as many large US and European-owned M-form corporations suffered from growing managerial diseconomies and 
low rates of innovation caused by size and diversification. The result was divestment of "noncore” businesses, outsourcing of many value-added activities once performed within corporate borders, and the formation of alliances with other firms which acted as suppliers and customers, or as partners in innovation. The second global economy became complex than previously as a result. While large corporations remained powerhouses of innovation spending and market power, they formed components of a worldwide web of inter-firm connections.

The disintegration of production systems and their replacement by networks of interfirm linkages lowered barriers for new entrants through. The growth of outsourcing to contract manufacturers, for example, created many opportunities for new entrants. In China, networks of small and medium-sized enterprises flourished as original equipment manufacturers, establishing influential positions in world supply chains in fields of low or mid-level technology. The growth of Galanz was one example. Founded in 1978 as a company that dealt in the trading of duck feathers, Galanz began producing OEM Toshiba-branded microwave ovens in 1993. Galanz later purchased the appliance division from Toshiba. By the following decade Galanz had become the world's largest microwave manufacturer. Within a network-type global economy, firms from emerging markets were able to piggy back on incumbent Western or Japanese firms as customers through subcontracting, linkages and leverages. Although they lacked the size and technological capabilities of incumbents there was the potential to grow through leveraging resources from others through joint ventures and contract relationships. ${ }^{117}$

If a major constraint for firms based in the Rest was not only the existence of entrepreneurial opportunities, but also the building of organizational capabilities to exploit them, 
then a number of developments during the second global economy alleviated this challenge, and facilitated “accelerated internationalization."118

First, diaspora assumed a renewed importance as transferors of entrepreneurship and capital, and means by which firms could access management talent. The revitalized use of diaspora reflected changes in policies in China and India especially made them more attractive locations to do business, encouraging diaspora to return. After 1980, ethnic Chinese firms based in Hong Kong and Taiwan, and later elsewhere, became the leading foreign investors as China liberalized its economy. They enjoyed connections (guanxi) in China, which reduced the transactions costs of investment by offering contacts with public authorities and inside information, and were welcomed by the Chinese government.

During the 1990s the Indian diaspora began to serve the same function in India. Although the Indian diaspora had its origins in the nineteenth century, when merchants and laborers had emigrated to other parts of Asia and Africa under the umbrella of the British Empire, a professional diaspora left India during the 1960s, often to the United States, seeking greater economic opportunities. Many engineers settled in Silicon Valley and made up a quarter of the workforce by the 1990s. As the Indian economy grew from the 1990s, there has been a significant reverse flow back to India. This was assisted by the Indian government's new policy in 2003 of granting dual nationality to some overseas Indian residents abroad. These diaspora links provided valuable connections between Silicon Valley and Bangalore, encouraging business connections and capital flows. ${ }^{119}$

Secondly, both business schools and management consultants provided much easier access to new management knowledge, and they have played important roles in building 
organizational capabilities in firms. In postwar Europe both US management consultancies and business schools were influential diffusers of American managerial knowledge to Europe and other developed countries. The impact on emerging markets only became stronger later. McKinsey opened in India in 1992. From the 1990s leading US business schools have internationalized their faculty and student body. During the 1950s and 1960s, although the Harvard Business School helped develop business schools in Turkey, India, Nicaragua and the Philippines, it remained primarily an American school in its ethos and teaching. However the percentage of US-born faculty decreased from 75 per cent in 1980 to 66 per cent in 2000. The student body moved from being almost entirely white American males in the 1950s, to being one third international in 2000.

Many of the most successful companies from emerging markets hired the leading US consulting firms for advice on strategy, sent senior managers on executive programs at the top business schools, and recruited MBAs as graduates. None of this meant that such firms evolved as replicas of US firms, but it did mean that they had faster and better access to information about the latest managerial ideas in ways which were impossible fifty years ago.

It is possible to see the influence of such conduits of managerial knowledge on the growth of global firms based in emerging markets such as CEMEX. After the 1980s the firm began to diversify from Mexico following the appointment of a new generation of the Zambrano family. Lorenzo Zambrano, the architect of a new international strategy, had been educated at Stanford Business School, and sought strategy advice from Boston Consulting Group. Responding to Mexican economic crisis, CEMEX began to expand internationally, initially in the US, but when blocked by anti-dumping judgment, to Europe. Cemex was a leading user of information technology. In 1987 Cemex created a satellite system to link the Mexican plants it 
hand begun to acquire. By the late 1990s it ranked as the third most profitable company in the world, and was the third largest cement company after Holderbank and Lafarge. By the following decade it was the largest cement company in the United States. ${ }^{120}$

A final, important, factor in the growth of MNEs from some emerging markets has support from their host governments. Both the nature and motives of this support has varied widely. Emerging market governments sought to intervene in many ways to help their firms overcome the information, transaction and resource constraints faced by their domestic firms. ${ }^{121}$ Some governments, including China, used state-owned firms as national champions to pursue strategic objectives. ${ }^{122}$ As governments from emerging markets often established ties with governments of other emerging countries, firms sometimes leveraged these contacts to facilitate their international growth. ${ }^{123}$ In many countries, firms formed contacts and associations at multiple levels of their home economy: city, provincial and national. ${ }^{124}$ This smart state capitalism differed from its post-war predecessor in being combined with competent management and execution, as well as being much more connected with the global economy.

The opportunities from a network-style world economy, the growth of organizational capabilities, and smarter government policies were not discrete factors in the growth of the new generation of MNEs based in emerging markets. These factors often combined to spur the growth of individual firms. This was evident in the growth of the internet router company Huawei Technologies, which was established in 1988 in the Shenzhen economic zone of China by Ren Zhengfei, a former major in the People’s Liberation Army. It began as a start-up small selling telephone-exchange equipment imported from Hong Kong, but grew rapidly after it began to make telecom equipment in the mid-1990s. By the new century it had become a leading 
supplier of digital switches and routers in China, and had secured 3 per cent of the world market for routers by producing equipment at lower prices than its Western competitors.

The firm's initial growth was facilitated by the founder's close association with the People's Liberation Army and credit from the state-owned development bank. Wireless networking was a strategic industry for the Chinese government, not least because the equipment was the hardware which enabled the government to censor information and monitor activity on the internet. However Huawei's growth was not a simple story of growth based on political contacts and support. Ren Zhengfei implemented a clever strategy of building businesses in remoter and outlying cities in China before targeting the major cities where Cisco and others had built a market since the 1990s. He then repeated the strategy globally, first selling to countries like Russia, Brazil and Thailand, before moving to more advanced markets, especially in Europe. Huawei also invested heavily in research, creating research centers in numerous locations around the world including Bangalore and Silicon Valley. Innovation was supported by an aggressive corporate culture which rewarded talent. The firm also benefitted from alliances with Western firms, with whom it collaborated as well as competed. In 2003 Huawei formed a joint venture with 3Com, then a leading US-owned router firm, designed to facilitate sales to US corporate customers. In 2007 Bain Capital, the private equity firm, and Huawei reached an agreement to acquire 3Com altogether for $\$ 2.2$ billion, but this was blocked by opposition by the Committee on Foreign Investment in the United States, an agency chaired by the Secretary of the Treasury. ${ }^{125}$ Although the US government continued to hinder Huawei’s growth in the United States, this did not prevent fast global expansion elsewhere. By 2012 Huawei was a \$32 billion company active in 140 countries, selling high-end internet networking equipment. ${ }^{126}$ 
The growth of powerful globally active MNEs from the Rest was a singular feature of the second global economy. There was no single driver, and it was not simply the result of policy liberalization. The new sources of knowledge acquisition provided by business schools and management consultancies, returning diaspora, smart state capitalism, and the changing nature of the global economy all contributed to a story which looks set to become one of the major shifts in world business history. Huawei and Cemex were tips of a growing iceberg of emerging market giants such as Tata in India, Brahma, Embraer, Sabó, and Aracruz in Brazil, Grupo Bimbo and Univision in Mexico. ${ }^{127}$ In more aggregate terms, the share of FDI from emerging markets in total outward FDI rose from 8.3 per cent to 15.9 per cent between 1990 and 2009. ${ }^{128}$

\section{Conclusion}

This working paper has sought to integrate the role of entrepreneurship and firms into debates on why the Rest was slow to catch up with the West following the Industrial Revolution and the advent of modern economic growth.

It was been suggested that poor human capital development and deficient institutions are important, but not sufficient, explanations. The emphasis on national-level institutions seems particularly unhelpful given strong regional variations in business activities between countries. The impact of institutions on the allocation of entrepreneurship between productive and redistributive activities takes the analysis to a deeper level, without entirely solving the problem, as the slow development of modern business in colonial India, and its skewed ownership, indicates. Entrepreneurs were also actors and not simply responders to institutions and resource endowments. They could train their own workers and they introduce investor protection into their own byelaws. 
It is evident that once the process of modern economic growth had started catch-up was surprisingly difficult in much of the Rest, if less so neighboring regions of the original North Sea industrializers. The societal and cultural embeddedness of new technologies posed significant entrepreneurial challenges in the Rest. The best equipped to overcome these challenges were often entrepreneurs based in minorities who held significant advantages in capital-raising and trust levels. They often also benefitted from a greater willingness to engage with Western firms and colonial governments. Generally, as the first global economy got underway, MNEs proved important facilitators of globalization, but they were a disappointing diffuser of organizational skills and information to the Rest, and had limited importance in relieving the institutional, human capital or other constraints faced by many local entrepreneurs.

By the interwar years there is considerable evidence of productive modern entrepreneurship and business enterprise emerging across Asia, Latin America and even Africa. Japan was a spectacular case of a more general process. This generation of entrepreneurs were sometimes facilitated by nationalistic governments and sentiments, and in China and elsewhere they were quite effective combining local and Western practices to produce hybrid forms of business enterprise. However many governmental policies after 1945 designed to facilitate catchup ended up crippling emergent business enterprises without putting an effective alternatives in place. They were too inward looking, and too inclined to incentivize inefficiency and corruption rather than innovation. Many policy regimes ended up favouring redistributive rather than productive entrepreneurship, although it was noteworthy that they also provided some shelter for local firms to develop without being crippled by competition from the West. Individual businesses had the agency either to invest in managerial and technological competences in this 
era, or alternatively focus on rent-seeking, but the rules of the game often made the first path the easier one.

The second global economy provided more opportunities for catch up from the Rest. Firms from emerging markets had the opportunity to access the global networks which, in part, replaced large integrated firms. There were new ways for firms in the Rest to access knowledge and capital, including returning diaspora, business schools and management consultancies. Smart state capitalism was a far greater source of international competitive advantage than the state intervention of the past, even if many government policies were not smart and continued to offer incentives for rent-seeking.

The rapid international growth of MNEs based in emerging markets was a striking departure from the past. However global capitalism also remained a system which rewarded winners, and facilitated clustering in favoured locations. Innovation remained heavily clustered in the advanced countries, especially the United States. Western and Japanese firms have powerful incumbency advantages. Falling tariff and other barriers meant that a new generation of firms based in the Rest might even find it harder to reach scale than their predecessors who could grow in the much-derided era of import substitution.

${ }^{1}$ This working paper originated as the annual Heckscher Lecture at the Stockholm School of Economics in 2006. I am grateful for Håkan Lindgren for the invitation to give this lecture, and for members of the original audience for many helpful comments. Subsequent drafts of this paper were presented at the European Business History Conference in Bergen in 2008, and at Bocconi University in 2013, and I would like to thank both audiences for their constructive advice. I would also like to thank Tom Nicholas for his valuable comments on an earlier draft. A 
revised version of this working paper is forthcoming in Geoffrey Jones, Entrepreneurship and Multinationals: Global Business and the Making of the Modern World (Northampton, MA: Edward Elgar, forthcoming fall 2013).

${ }^{2}$ Kenneth Pomeranz, The Great Divergence (Princeton: Princeton University Press, 2000).

${ }^{3}$ Stephen Broadberry and B. Gupta,’The early modern great divergence: wages, prices and economic development in Europe and Asia, 1500-1800”, Economic History Review, 59, 1, (2006), pp. 2-31; Jan Luiten van Zanden, “The Skill Premium and the 'Great Divergence,” European Review of Economic History, 13, (2009), pp. 121-153; Robert C. Allen, Jean-Pascal Bassino, Debin Ma, Christine Moll-Murata and Jan Luiten van Zanden, "Wages, Prices, and Living Standards in China, Japan, and Europe, 1738-1925," Economic History Review, 64, 1 (2011), pp. 8-38; Bozhong Li and Jan Luiten van Zanden, "Before the Great Divergence? Comparing the Yangzi Delta and the Netherlands at the Beginning of the Nineteenth Century,” Journal of Economic History, 72, 4 (2012), pp.956-989.

${ }^{4}$ Agustin S. Bénétrix, Kevin H. O’Rourke and Jeffrey G. Williamson, "The Spread of Manufacturing to the Periphery 1870-2007: Eight Stylized Facts” (mimeo July 2012).

${ }^{5}$ A.D. Chandler, Strategy and Structure (Cambridge, MA: Harvard University Press, 1962); Idem, The Visible Hand (Cambridge, MA: Harvard University Press, 1977) and Idem, Scale and Scope (Cambridge, MA: Harvard University Press, 1990). See also William Lazonick and David J. Teece (eds.) Management Innovation. Essays in the Spirit of Alfred D. Chandler, Jr. (Oxford: Oxford University Press, 2012). 
${ }^{6}$ James Foreman-Peck and Leslie Hannah, "Extreme divorce: the managerial revolution in UK companies before 1914,” Economic History Review, 65, 4 (2012), pp. 1217-1238.

${ }^{7}$ Douglass C. North, Institutions, Institutional Change, and Economic Performance (Cambridge: Cambridge University Press, 1990). p. 97.

${ }^{8}$ Avner Greif, Institutions and the Path to the Modern Economy: Lessons from Medieval Trade (Cambridge: Cambridge University Press, 2006), p.30.

9 Douglass C. North, Understanding the Process of Economic Change (Princeton University Press: Princeton, 2005).

${ }^{10}$ Douglass C. North and Barry R. Weingast, "Constitutions and Commitment: The Evolution of Institutional Governing Public Choice in Seventeenth-Century England” Journal of Economic History 49, 4 (1989), pp. 803-832. For the subsequent debate on this issue, see Steven C.A. Pincus and James A. Robinson, "What really happened during the Industrial Revolution,” NBER Working Paper 17206 (July 2011).

${ }^{11}$ Stanley L. Engerman and Kenneth L. Sokoloff, “Colonialism, Inequality, and Long-Run Paths of Development,” in Abhijit Vinayak Banerjee, Roland Bénabou and Dilip Mookherjee (eds.) Understanding Poverty (Oxford: Oxford University Press, 2006), pp. 37-61; Idem, Economic Development in the Americas since 1500 (New York; Cambridge University Press, 2012).

${ }^{12}$ Daron Acemoglu, Simon Johnson, James A. Robinson, "Reversal of Fortune: Geography and Institutions in the Making of the Modern World Income Distribution”, The Quarterly Journal of Economics, 117, 4 (2002), pp. 1231-1294.

${ }^{13}$ Rafael La Porta, Florencio Lopez-de-Silanes, Andrei Shleifer \& Robert W. Vishny, 1998. "Law and Finance," Journal of Political Economy, 106, 6, (1998), pp. 1113-1155; Rafael La 
Porta, Florencio Lopez-de-Silanes, Andrei Shleifer, Robert Vishny, "Investor protection and corporate governance," Journal of Financial Economics, 58, 1-2, (2000), pp. 3-27.

${ }^{14}$ Richard A. Easterlin, “Why Isn't the Whole World Developed?” The Journal of Economic History, 41, 1 (1981), pp. 1-19.

${ }^{15}$ Claudia Goldin, “The Human-Capital Century and American Leadership” Journal of Economic History, 61, 2 (June 2001), pp. 263-91. See also Claudia Goldin and Lawrence Katz, The Race between Education and Technology (Cambridge, MA: Harvard University Press, 2008).

16 Edward L. Glaeser, Rafael La Porta, Florencio Lopez-De-Silanes and Andrei Shleifer, "Do Institutions Cause Growth,” Journal of Economic Growth, 9, 3 (2004), pp. 271-303.

${ }^{17}$ Kent Deng, "A Critical Survey of Recent Research in Chinese Economic History," Economic History Review, LIII, 1 (February 2000), pp. 1-28; David Faure, China and Capitalism (Hong Kong: Hong Kong University Press, 2006), chapter 2.

${ }^{18}$ Justin Yifu Lin 1995, "The Needham Puzzle: Why the Industrial Revolution Did Not Originate in China," Economic Development and Cultural Change, 43, 2 (1995), pp. 269-92.

${ }^{19}$ Max Weber, The Protestant Ethic and the Spirit of Capitalism (Oxford: Oxford University Press, 2011 ed.).

${ }^{20}$ Joel Mokyr, The Lever of Riches (Oxford: Oxford University Press, 1990), chapter 9.

${ }^{21}$ Steven A. Sass, "Entrepreneurial Historians and History: An Essay in Organized Intellect" (PhD diss, John Hopkins University, 1977).

${ }^{22}$ David S. Landes, “French Entrepreneurship and Industrial Growth in the Nineteenth Century,” Journal of Economic History 9 (1949), pp. 245-72.

${ }^{23}$ David S. Landes, The Wealth and Poverty of Nations (New York; W.W. Norton, 1998). 
24 The classic work is Martin Wiener, English Culture and the Decline of the Industrial Spirit, 1850-1980 (Cambridge: Cambridge University Press, 1981)

${ }^{25}$ Michael S. Smith, The Emergence of Modern Business Enterprise in France, 1800-1930 (Cambridge MA: Harvard University Press, 2006).

${ }^{26}$ Alexander Gershenkron, “Social Attitudes, Entrepreneurship, and Economic Development: A Comment,” Explorations in Entrepreneurial History, 6 (1954), pp.245-272.

27 Joseph Schumpeter, “The Creative Response in Economic History”, Journal of Economic History, 7 (1947), pp. 149-159.

${ }^{28}$ Angus Maddison, Monitoring the World Economy 1820-1992 (Washington DC: Organization for Economic Co-operation and Development, 1995)

${ }^{29}$ William J. Baumol, “Entrepreneurship: Productive, Unproductive, and Destructive,” Journal of Political Economy, 98, 5 (1990), pp. 893-921.

${ }^{30}$ David S. Landes, Joel Mokyr and William J. Baumol, (eds.) The Invention of Enterprise: Entrepreneurship from Ancient Mesopotamia to Modern Times (Princeton: Princeton University Press, 2010).

31 Noel Maurer, The Power and the Money. The Mexican Financial System, 1876-1932 (Stanford: Stanford University Press, 2002)

32 Yovanna Pineda, “Financing Manufacturing Innovation in Argentina, 1890-1930,” Business History Review, 83 (2009), pp. 539-562.

33 Tirthankar Roy, "Did Globalization Aid Industrial Development in Colonial India? A Study of Knowledge Transfer in the Iron Industry,” Indian Economic and Social History Review, 46, 4 (2009), pp. 579-613. 
${ }^{34}$ Edward Beatty, “Approaches to technology transfer in History and the Case of Nineteenth Century Mexico,” Comparative Technology Transfer and Society, 1, 2 (2003), pp. 167-200; Idem, "Bottles for Beer: The Business of Technological Innovation in Mexico, 1890-1920," Business History Review, 83 (2009), pp. 317-348.

${ }^{35}$ Mario Cerutti, “Estudios regionals e historia empresarial en Mexico (1840-1920): Una revision de lo producido desde 1975," in Carlos Davilla (ed.) Empresa e historia en América Latina (Bogota: Tercer Mundo/Colciendas, 1996); Carlos Davilla, Empresas y empresarios en la Historia de Colombia: Siglos XIX y XX (Bogota: Norma/Uniandes, 2003).

${ }^{36}$ For the Meiji Restoration, see Andrew Gordon, A modern history of Japan: from Tokugawa times to the present (New York: Oxford University Press, 2003); Seiichiro Yonekura and Hiroshi Shimizu, "Entrepreneurship in Pre-World War 11 Japan: the Role and Logic of the Zaibatsu,” in Landes et al, Invention, pp.506-507.

37 William D. Wray, Mitsubishi and the N.Y.K., 1870-1914:business strategy in the Japanese shipping industry (Cambridge, MA: Harvard University Press, 1984)

38 Joel Mokyr, "Intellectual Property Rights, the Industrial Revolution, and the beginnings of modern economic growth," American Economic Review Papers and Proceedings, 99, 2 (2009), pp. 349-355; Josh Lerner, “150 Years of Patent Protection”, NBER Working Paper 7478 (2000).

39 Winfried Ruigrok and Rob van Tulder, The Logic of International Restructuring (London: Routledge, 1995), pp. 213-214.

40 Petra Moser, "Patent Laws and Innovation: Evidence from Economic History", NBER Working Paper 18631(December 2012). 
${ }^{41}$ Faure, China, chapter 4; William C. Kirby, “China Unincorporated: Company Law and Business Enterprise in Twentieth-Century China,” Journal of Asian Studies, 54, 1 (1995), pp. 4363.

${ }^{42}$ Aldo Musacchio, "Can Civil Law Countries get Good Credit Institutions? Lessons from the History of Creditor Rights and Bond Markets in Brazil,” Journal of Economic History, 68, 1 (2008), pp. 80-108.

${ }^{43}$ A. G. Hopkins, “Big Business in African Studies,” Journal of African History, 28, 1 (1987), pp. 119-40.

${ }^{44}$ Ina B. McCabe, Gelina Harlaftis, and Ioanna P. Minoglou (eds.), Diaspora Entrepreneurial Networks: Four Centuries of History (Oxford: Berg, 2005); Gijsbert Oonk, The Karimjee Jivanjee Family. Merchant Princes of East Africa 1800-2000 (Amsterdam: Pallas Publications, 2009).

${ }^{45}$ Susan Wolcott, "An Examination of the Supply of Financial Credit to Entrepreneurs in Colonial India,” in Landes et al, Invention, pp. 443-468.

${ }^{46}$ Dwijendra Tripathi, Oxford History of Indian Business (New Delhi: Oxford University Press, 2004); Claude Markovits, Merchants, traders, entrepreneurs: Indian business in the colonial era (New York: Palgrave Macmillan, 2008).

${ }^{47}$ Tirthankar Roy, The Economic History of India 1857-1947 (New Delhi: Oxford University Press, 1947), chapter 7; Idem, "Economic History and Modern India: Redefining the Link," Journal of Economic Perspectives, 16, 3 (2002), pp. 117-8.

${ }^{48}$ Ronald P. Dore, “Education; Japan,” in Robert E. Ward and Dankwart A. Rustow (eds.), Political Modernization in Japan and Turkey (Princeton: Princeton University Press, 1964), pp. 
176-204. A more critical study was provided in Koji Taira, "Education and Literacy in Meiji Japan: An Interpretation,” Explorations in Economic History, 8, 4 (1971), pp. 371-94.

${ }^{49}$ Ulf Olsson, "Securing the markets. Swedish Multinationals in a historical perspective," in Geoffrey Jones and Harm G. Schröter (eds.) The Rise of Multinationals in Continental Europe (Aldershot: Edward Elgar, 1993), pp.100-102.

${ }^{50}$ Deng, “Critical.”

${ }^{51}$ Stanley L. Engerman with Elisa Mariscal, “The Evolution of Schooling, 1800-1925,” in Stanley L. Engerman and Kenneth L. Sokoloff (eds.) Economic Development in the Americas since 1500. Endowments and Institutions (Cambridge: Cambridge University Press, 2012), pp. $121-167$.

${ }^{52}$ Michael Y. Yoshino and Thomas B. Lifson, The Invisible Link. Japan's Sogo Shosha and the organization of Trade (Cambridge, MA: MIT Press, 1986).

${ }^{53}$ Tripathi, Oxford.

${ }^{54}$ Morris D. Morris, “Large-Scale Industrial Development,” in Dharma Kumar and Meghnad Desai (eds.) Cambridge Economic History of India (Cambridge: Cambridge University Press, 1983), pp. 553-676.

${ }^{55}$ North, Understanding, pp. 42, 46.

${ }^{56}$ Geert Hofstede and Michael Harris Bond, "The Confucius Connection: From Cultural Roots to Economic Growth," Organizational Dynamics, Vol. 16, No. 4 (1988), pp.4-21 Geert Hofstede, Gert Jan Hofstede, and Michael Minkov, Cultures and Organizations: Software of the Mind, Third Edition (New York: McGraw-Hill, 2010).

${ }^{57}$ Yat Hoong Yip, The development of the tin mining industry of Malaya (Kuala Lumpur, University of Malaya Press, 1969); Jean-Jacques van Helten and Geoffrey Jones, "British 
business in Malaysia and Singapore since the 1870s,” in R.P.T. Davenport-Hines and Geoffrey Jones (eds.), British Business in Asia since 1860 (Cambridge; Cambridge University Press, 1989), pp.165-66; John Hillman, The International Tin Cartel (London: Routledge, 2010), chapter 3.

${ }^{58}$ Mark Casson, The Economics of Business Culture (Oxford: Clarendon Press, 1991); Idem, Entrepreneurship and Business Culture (Cheltenham: Edward Elgar, 1995); Mark Casson and Andrew Godley (eds.) Cultural Factors in Economic Growth (New York : Springer, 2000)

${ }^{59}$ Andrea Colli and Mary Rose, "Family Capitalism”, in Jones and Zeitlin (eds.) Oxford Handbook, pp. 194-218.

${ }^{60}$ Tarun Khanna and Yishay Yafeh. "Business Groups in Emerging Markets: Paragons or Parasites?" in Asli M. Colpan, Takashi Hikino and James R. Lincoln (eds.) The Oxford Handbook of Business Groups (Oxford: Oxford University Press, 2010); Tarun Khanna and Krishna G. Palepu, "The Future of Business Groups in Emerging Markets: Long-Run Evidence from Chile." Academy of Management Journal 43, 3 (2000): Geoffrey Jones and Tarun Khanna, "Bringing History (Back) into International Business," Journal of International Business Studies 37, 4 (2006), pp. 453-468.

${ }^{61}$ Tripathi, Oxford.

${ }^{62}$ Christopher A. Reed, Gutenberg in Shanghai. Chinese Print Capitalism 1876-1937 (Honolulu: University of Hawaii Press, 2004); Wellington K.K. Chan, “Chinese Entrepreneurship since Its Late Imperial Period,” in Landes, et al (eds.) Invention, pp. 489-491.

${ }^{63}$ For the role of French immigrants in Mexican textiles, see Aurora Gómez-Galvarriato, "Networks and Entrepreneurship: The Modernization of the Textile Business in Porfirian Mexico,” Business History Review, 82 (2008), pp. 475-502. 
${ }^{64}$ Ashok Desai, “The Origins of Parsi Entrepreneurship,” Indian Economic and Social History Review, 5, 4 (1968), pp. 307-18; Christine Dobbin, Urban Leadership in Western India. Politics and Communities in Bombay City, 1840-1885 (Oxford: Oxford University Press, 1972); Idem, Asian Entrepreneurial Minorities: Conjoint Communities in the Marking of the World-Economy 1570-1940 (Richmond: Curzon Press, 1996).

${ }^{65}$ Omkar Goswami, "Then Came the Marwaris: Some Aspects of the Changes in the Pattern of Industrial Control in Eastern India", Indian Economic and Social History Review 22 (1985), pp. 225-49; Thomas A Timburg, The Marwaris, from traders to industrialists (New Delhi: Vikas, 1978).

${ }^{66}$ Wolcott, “Examination,” pp. 443- 468.

${ }^{67}$ Tirthankar Roy, “Beyond Divergence: Rethinking the Economic History of India,” Economic History of Developing Regions, 27, 1 (2012), p. S62.

${ }^{68}$ Alexander Gershenkron, Economic Backwardness in Historical Perspective (Cambridge, MA: Belknap Press, 1962).

${ }^{69}$ Jones and Wadhwani, “Entrepreneurship,” pp. 513-14.

${ }^{70}$ Steven Tolliday (ed.), The Economic Development of Modern Japan, 1868-1945, vol. 1 (Cheltenham: Edward Elgar, 2001), pp. xiv-xv.

${ }^{71}$ Rajeswary Ampalavanar Brown, Chinese Big Business and the Wealth of Nations (London: Palgrave, 2000).

${ }^{72}$ William W. Culver and Cornell J. Reinhart, “Capitalist Dreams: Chile’s Response to Nineteenth Century World Copper Competition,” Comparative Studies in Society and History, 31 (1989), pp. 722-744.

${ }^{73}$ Geoffrey Jones, British Multinational Banking 1830-1990 (Oxford: Clarendon Press, 1993). 
${ }^{74}$ Emily S. Rosenberg, Financial Missionaries to the World: the politics and culture of dollar diplomacy, 1900-1930 (Cambridge, MA: Harvard University Press, 1999).

${ }^{75}$ John H. Dunning and Sarianna M. Lundan, Multinational Enterprises and the Global Economy (Cheltenham: Edward Elgar, 2008), pp. 172-6.

${ }^{76}$ Jones, British Multinational Banking; Frank H.H. King, The Hongkong Bank in late imperial China, 1864-1902: on an even keel (Cambridge: Cambridge University Press, 1987).

${ }^{77}$ Yen-Ping Hao, The Commercial Revolution in Nineteenth-century China: the Rise of SinoWestern Mercantile Capitalism (Berkeley: University of California Press, 1986).

${ }^{78}$ William J. Hausman, Peter Hertner and Mira Wilkins (eds.), Global Electrification (New York: Cambridge University Press, 2008).

79 Caroline Piquet, “The Suez Company’s Concession in Egypt, 1854-1956: Modern Infrastructure and Local Economic Development,” Enterprise \& Society 5/1 (2004), pp. 107-127: Daniel R. Headrick, The Tentacles of Progress: Technology Transfer in the Age of Imperialism, 1850-1940 (New York: Oxford University Press, 1988).

${ }^{80}$ Mark Mason, American Multinationals and Japan (Cambridge, MA: Harvard University Press, 1992).

${ }^{81}$ Priscilla Connolly, "Pearson and Public Works Construction in Mexico, 1890-1910,” Business History 41, 4 (1999); Lisa Bud-Frierman, Andrew Godley, and Judith Wale, "Weetman Pearson in Mexico and the Emergence of a British Oil Major, 1901-1919,” Business History Review 84 (Summer 2010), pp. 275-300.

${ }^{82}$ Stephen Schlesinger and Stephen Kinzer, Bitter fruit: the story of the American coup in Guatemala (Cambridge, MA: Harvard University, David Rockefeller Center for Latin American Studies, 1999). 
${ }^{83}$ Jones, Multinationals.

${ }^{84}$ Victoria de Grazia, Irresistible Empire. America's Advance through $20^{\text {th }}$-Century Europe (Cambridge, MA: Harvard University Press, 2005).

${ }^{85}$ Michael Miller, Europe and the Maritime World (Cambridge: Cambridge University Press, 2011), p.10.

${ }^{86}$ Jones. Entrepreneurship, chapter 1.

${ }^{87}$ Tripathi, Oxford History.

${ }^{88}$ Madeleine Zelin, The Merchants of Zigong (New York: Columbia University Press, 2005);

Kai Yiu Chan, Business Expansion and Structural Change in Pre-war China (Hong Kong: Hong Kong University Press, 2006).

${ }^{89}$ Elisabeth Koll, From Cotton Mill to Business Empire (Cambridge, MA: Harvard University Press, 2003).

${ }^{90}$ Sherman Cochran, Chinese Medicine Men. Consumer Culture in China and Southeast Asia (Cambridge, MA: Harvard University Press, 2006).

91 Eric Davis, Challenging Colonialism: Bank Miṣr and Egyptian industrialization, 1920-1941 (Princeton, N.J: Princeton University Press, 1983); Robert L. Tignor, State, Private Enterprise, and Economic Change in Egypt, 1918-1952 (Princeton, N.J. : Princeton University Press, 1984); Idem, “The Economic Activities of Foreigners in Egypt, 1920-1950: From Millet to Haute Bourgeoisie,” Comparative Studies in Society and History, 22, 3 (July 1980), pp. 416-449.

${ }^{92}$ Asli M. Coplan and Geoffrey Jones, “Vehbi Koç and the Making of Turkey’s Largest Business Group”, Harvard Business School Case, 9-811-081, November 202012.

93 Jones, Multinationals, p. 99. 
94 Dunning and Lundan, Multinational, pp. 31-32, 175, 185-6; Jones, Multinationals, pp. 22-23, 33-35.

95 Alfred D. Chandler, Inventing the Electronic Century (New York: Free Press, 2001); Carl Dassbach, Global Enterprises and the World Economy (New York: Garland, 1989)

${ }^{96}$ Christophe Lécuyer. Making Silicon Valley: Innovation and the Growth of

High Tech, 1930-1970 (Cambridge, MA: The MIT Press, 2006).

97 John A. Cantwell, “The Globalization of Technology: What Remains of the Product Cycle Model?” Cambridge Journal of Economics, 19 (195), pp.155-74

98 Daniele Archibugi and Simona Iammarino, “Innovation and Globalization”, in Francois Chesmais, Grazia Ietto-Gillies and Roberto Simonetti (eds.), European Integration and Global Corporate Strategies (London: Routledge, 2000), pp. 95-120.

${ }^{99}$ Geoffrey Jones, Renewing Unilever (Oxford: Oxford University Press, 2005). For the case of a Citibank manager who became an Indian IT entrepreneur, see R. Daniel Wadhwani, “Jerry Rao: Diaspora and Entrepreneurship in the Global Economy”, Harvard Business School Case No. 805017 (February 2008).

100 Geoffrey Jones, Beauty Imagined (Oxford: Oxford University Press, 2010).

${ }^{101}$ For an introduction to the economic history of the Communist world, see Gabriel Tortella, The Origins of the Twenty First Century (London; Routledge, 2010), chapter 11. See also Andrei Yudanov, "USSR: Large enterprises in the USSR - the functional disorder," in Alfred D. Chandler, Franco Amatori, and Takashi Hikino (eds.), Big Business and the Wealth of Nations (Cambridge: Cambridge University Press, 1997).

${ }^{102}$ Greg Huff, The Economic Growth of Singapore: Trade and Development in the Twentieth Century (Cambridge: Cambridge University Press, 1997); S. Y. Wong The Business and 
Sustainability of Water Supply in Singapore: The Case of Hyflux” in Jay D. Gatrell and Neil Reid (eds.), Enterprising Worlds (Dordrecht: Springer, 2006), pp. 145-163; Rohit Deshpande and Hal Hogan, "Singapore Airlines: Customer Service Innovation,” Harvard Business School Case no 504025 (April 2011).

${ }^{103}$ Greg Huff, The Economic Growth of Singapore: Trade and Development in the Twentieth Century, (Cambridge: Cambridge University Press, 1997); Hafiz Mirza, Multinationals and the Growth of the Singapore Economy, Beckenham: Croom Helm, 1986).

${ }^{104}$ Rajah Rasiah, "The Importance of Size in the Growth and Performance of the Electrical Industrial Machinery and Apparatus Industry in Malaysia,” in Chris Nyland, Wendy Smith, Russell Smyth, Marika Vicziany (eds.), Malaysian Business in the New Era (Cheltenham: Edward Elgar, 2001): Peter G. Warr, “Malaysia's Industrial Enclaves: Benefits and Costs,” The Developing Economies, XXV, 1 (1987), pp. 30-55.

${ }^{105}$ Mason, American.

${ }^{106}$ Alice H. Amsden, Asia's Next Giant: South Korea and Late Industrialisation (Oxford: Oxford University Press, 1989); Idem, The Rise of "the Rest": Challenges to the West from LateIndustrializing Countries (Oxford: Oxford University Press, 2003).

${ }^{107}$ Charles F. Geddes, Patiño, the tin king (London: R. Hale, 1972).

${ }^{108}$ Charles H. Feinstein, An Economic History of South Africa: Conquest, Discrimination and Development ( Cambridge: Cambridge University Press, 2005).

109 Rajeswary A Brown, “Overseas Chinese Investments in China-Patterns of Growth, Diversification and Finance: The Case of Charoen Pokphand,” China Quarterly, 155 (1998), pp. 610-636; Pavida Pananond, “The Making of Thai Multinationals: The Internalisation process of Thai Firms” (unpublished University of Reading PhD, 2001). 
110 Helen Shapiro, Engines of Growth. The State and Transnational Auto Companies in Brazil (Cambridge: Cambridge University Press, 1994)

111 Balaji Parthasarathy and Yuko Aoyama, "From software services to R\&D services: local entrepreneurship in the software industry in Bangalore, India,” Environment and Planning A, 38 (2006), pp. $1269-1285$.

${ }^{112}$ Erza F. Vogel, Deng Xiaoping and the transformation of China (Cambridge, MA: Belknap Press, 2011).

${ }^{113}$ Yasheng Huang, Selling China: foreign direct investment during the reform era (Cambridge: Cambridge University Press, 2003).

114 Laura Alfaro and Andres Rodriguez-Clare. "Multinationals and Linkages: An Empirical Investigation." Economía (spring 2004).

${ }^{115}$ Anil K. Gupta and Vijay Govindarajan,“Knowledge Flows Within Multinational Corporations. Strategic Management Journal 21(4) (2000), pp. 473-496; Nicolai Foss and Torben Pedersen, “Transferring Knowledge in MNCs: The Roles of Sources of Subsidiary Knowledge and Organizational Context,” Journal of International Management 8 (2002), pp. 1-19.

${ }^{116}$ Geoffrey Jones and David Kiron, "Cisco Goes to China: Routing an Emerging Economy,” Harvard Business School Case 805-020 (June 2012).

117 John A. Mathews, Dragon Multinational. A New Model for Global Growth (Oxford: Oxford University Press, 2002).

118 John A Matthews and Ivo Zander, “The international entrepreneurial dynamics of accelerated internationalization,” Journal of International Business Studies, 38 (2007), pp. 387403.

119 Abhishek Pandey, Alok Aggarwal, Richard Devane, and Yevgency Kuznetsov, “India’s 
Transformation to Knowledge-Based Economy - Evolving Role of the Indian Diaspora,” Evalueserve (July 2004), http://info.worldbank.org/etools/docs/library/152386/abhishek.pdf.

${ }^{120}$ Donald R. Lessard and Cate Reavis, “CEMEX: Globalization “The Cemex Way,” MITSloan Management Case, 09-039 (March 2009).

121 Tarun Khanna, Krishna Palepu, and Jayant Sinla,“Strategies that fit emerging markets”, Harvard Business Review, 83, 3 (2005), pp. 6-15.

122 John Child and Suzana.B. Rodriques, "The internationalization of Chinese firms: A case for theoretical extension?” Management and Organization Review, 1, 3 (2005), pp. 381-418.

123 Jing-Lin Duanmu, "Firm heterogeneity and location choice of Chinese multinational enterprises,” Journal of World Business, 47, 1 (2012), pp.64-72.

124 Chengqi Wang, Junjie Hong, Mario Kafouros and Mike Wright, "Exploring the role of government involvement in outward FDI from emerging markets," Journal of International Business Studies, 43 (2012), pp. 655-676.

125 “China Fear Scuppers \$2 billion deal for 3Com,” Financial Times, February 212008.

126 “The Company that spooked the world,” The Economist, August 4 2012, pp. 19-23.

${ }^{127}$ Donald N. Sull and Martin Escobari, Success Against the Odds (Sao Paulo: Elsevier, 2005).

${ }^{128}$ Ravi Ramamurti, “What is really different about emerging market multinationals?” Global Strategy Journal, 2, 1 (2012), pp.41-47. 